\title{
The Impact of Domestic CSR on the Internationalisation of Emerging-Market Multinational Enterprises: Evidence from India
}

\author{
Vikrant Shirodkar ${ }^{1}$ (D) Namita Shete ${ }^{2}$
}

Received: 20 May 2020 / Revised: 3 November 2021 / Accepted: 9 November 2021 /

Published online: 27 January 2022

(c) The Author(s) 2022

\begin{abstract}
Emerging-market multinational enterprises (EMNEs) are, on the one hand, investing in both developed and developing countries aggressively. On the other hand, they are facing greater pressures from their home and host countries to operate in a socially responsible manner. In this paper, combining institutional theory with strategic perspectives on corporate social responsibility (CSR), we argue that EMNEs spending on CSR more intensively in their domestic context are likely to have a greater scope of internationalisation. We also argue that this effect decreases for government-owned EMNEs and increases when EMNEs target developed host markets or institutionally stronger emerging markets. Our data used to test our hypotheses are based on a sample of 686 Indian firms. Our findings provide support for most of our arguments, and we contribute to a greater understanding of the relationship between CSR and internationalisation.
\end{abstract}

Keywords Corporate social responsibility · Internationalisation · Emerging market multinational enterprises $\cdot$ International business $\cdot$ Liabilities of origin

\section{Introduction}

The internationalisation of firms from emerging economies is gaining widespread academic attention, as these new types of multinationals are increasingly engaging in foreign direct investment (FDI) in both developed and developing countries (Awate

Vikrant Shirodkar

V.Shirodkar@sussex.ac.uk

Namita Shete

N.S.Shete@cranfield.ac.uk

1 University of Sussex Business School, University of Sussex, Brighton BN1 9SL, UK

2 Cranfield School of Management, Cranfield University, Cranfield MK43 OAL, Bedfordshire, UK 
et al., 2012; Buckley, 2018; Buckley et al., 2014, 2015; Friel, 2021; Hernandez \& Guillén, 2018; Pattnaik et al., 2021). Emerging-market multinational enterprises (EMNEs) are catching up with their developed country counterparts by upgrading their technological capabilities via foreign acquisitions and alliances. However, they are also known to face additional barriers to internationalisation due to their weaker home institutions and due to their relative newness to international business, which consequently results in a negative perception of EMNEs among stakeholders in host countries (Marano et al., 2017).

In this context, we suggest that less is known about the extent to which EMNEs' domestic corporate social responsibility (CSR) (i.e., CSR conducted in their home country) impacts their internationalisation prospects. Understanding this connection can be important for a variety of reasons. First, CSR activities are becoming important not only for gaining legitimacy but also for contributing to the government's developmental initiatives within emerging economies (Caussat et al., 2019; Hadjikhani et al., 2019; Hah \& Freeman, 2014; Zheng et al., 2015). The predominant notion of CSR among companies operating in emerging economies is that philanthropic activities generate a 'social licence to operate' and reduce the risk of being accused of unethical or irresponsible behaviour (Krichewsky, 2019; Rajak, 2011). The benefits accrued through CSR can become important firm-specific advantages for EMNEs in regard to improving their internationalisation prospects (Ramamurti, 2012). Specifically, we expect that the legitimisation and reputational advantages engendered through CSR can potentially reduce EMNEs' 'liabilities of origin' during internationalisation (Attig et al., 2016; Marano \& Tashman, 2012; Marano et al., 2017).

Second, despite the heterogeneity in the institutional characteristics of various emerging economies, governments in many emerging economies have been tightening regulations regarding CSR. Within developed countries, CSR reporting laws such as those in France and Denmark, the Swedish sustainability legislation, the Scottish Sustainable Procurement Action Plan and the Canadian Green Procurement Policy are well-known examples of CSR and sustainability-related regulations. Among the emerging economies, Mauritius was the first to implement mandatory CSR legislation in 2009, followed by India, who, in 2013, made it mandatory for firms to spend funds on CSR. In India, which forms the context of our study, CSR legislation requires medium-to-large companies to spend $2 \%$ of their average net profits gained over the previous three years on socioeconomic development activities, which fall under a broad set of themes specified under schedule VII of the Companies Act of 2013. While such regulations encourage firms to actively contribute to sustainable development, they also increase operational costs for firms. EMNEs, in particular, are technologically resource-constrained compared to their counterparts from developed countries (Ramamurti, 2012). Therefore, it is important to examine whether EMNEs indeed benefit from their domestic CSR insofar as their effects on internationalisation are concerned. Based on this, our key research question is as follows: To what extent does domestic CSR impact the internationalisation of EMNEs?

To answer this question, we rely on a sample of 686 firms from India, which includes a wide range of large and medium-sized firms operating in a variety of industries. We also test the moderating effects of EMNEs' government ownership 
and the nature of the target market on the relationship between EMNEs' domestic CSR and their scope of internationalisation. Government (or state) ownership forms an important feature of many EMNEs and is closely associated with their internationalisation prospects, as per past studies (Cui \& Jiang, 2012; Zhou, 2018). Government ownership engenders EMNEs with 'ascribed' nonmarket advantages that can be used to facilitate internationalisation (Deng et al., 2018). Similarly, the target market of the EMNE can play an important moderating role in the effect of EMNEs' domestic CSR on their scope of internationalisation. This is because the liabilities of origin that EMNEs face during internationalisation are likely to be more pronounced when EMNEs invest in developed countries or in institutionally stronger emerging economies (Marano et al., 2017). As such, EMNEs' domestic CSR can be expected to create greater legitimisation advantages when they invest in such host countries.

We contribute to prior research on EMNEs' internationalisation in a number of ways. First, we explain the association between domestic CSR and internationalisation by focusing on EMNEs. EMNEs are distinctively known to engage in internationalisation to (1) escape home-institutional 'constraints' and (2) leverage their home-based nonmarket 'advantages' to facilitate internationalisation (CuervoCazurra, 2008; Marano et al., 2017; Nuruzzaman et al., 2020). Prior studies have examined the role of EMNEs' 'domestic' nonmarket advantages on their internationalisation scope; however, most of these studies have focused on the role of EMNEs' political connections (Deng et al., 2018; Du \& Luo, 2016). We argue that domestic CSR provides EMNEs with similar nonmarket advantages to improve their internationalisation prospects and that EMNEs' ownership structures (private vs. government owned) and the target market where they seek to internationalise moderate this relationship. Second, we contribute to the recent set of studies, which suggest that EMNEs' CSR can reduce their liabilities of origin when investing overseas (Marano et al., 2017; Tashman et al., 2019). Prior studies in this context have focused on EMNEs' CSR communication, and we contribute by examining CSR expenditures, which potentially provide a more realistic account of CSR. Third, we focus on EMNEs' internationalisation based on their ability to create a foreign subsidiary versus a domestic subsidiary. Prior research on EMNEs' internationalisation has largely focused on their exporting behaviour. However, this trend has increasingly changed in recent years, and EMNEs are committing more to international markets through foreign direct investment (FDI). As such, we contribute to this new range of studies that focus on EMNEs' outward FDI (Witt \& Lewin, 2007; Xia et al., 2014; Yan et al., 2018). Finally, we make an important contribution by focusing on the context of India, where regulations concerning CSR have recently developed in a distinctive way (by making CSR spending mandatory); however, thus far, few studies have focused on this issue (Aswani et al., 2020; Subramaniam et al., 2017). Past research on the internationalisation of EMNEs has largely focused on China. By focusing on India, the second-largest emerging economy, we also try to fill the focus gap by looking at a different yet relevant context.

In the following sections, we first provide a background to theory, followed by developing our hypotheses on the relationship between domestic CSR and internationalisation and on the moderating effects of government ownership and the target market of internationalisation. This is followed by the description of our methods. 
We then present our results from our empirical analysis, which is finally followed by discussion and conclusions.

\section{Theoretical Background and Hypotheses}

Most prior research on the firm-specific advantages (FSAs) driving the internationalisation of firms has focused on firms' possession of 'market-based' assets, such as innovative products, superior management capabilities and managers' international experience, which enable them to seek rents from a variety of international markets (Buckley \& Casson, 1998; Dunning, 2000; Erramilli et al., 1997; Kotha et al., 2001; Rugman \& Verbeke, 1992; Scott-Kennel \& Giroud, 2015). However, recent research on the factors motivating EMNEs' internationalisation suggests that the development of such market-based FSAs does not fully explain their internationalisation behaviour. EMNEs' 'nonmarket' advantages generated through their embedding within both home- and host-country institutions significantly complement their market-based FSAs in internationalisation (Bhaumik et al., 2016; Wei \& Nguyen, 2017).

Institutions comprise both formal (regulatory) and informal (normative, cultural) forces that define the 'rules of the game' (North, 1996). In most emerging economies, formal institutions are weak and are characterised by institutional 'voids', which are manifested through, for instance, information asymmetries, ambiguities in regulations, and ineffective control-enforcing mechanisms (Khanna \& Palepu, 2000). Institutional weaknesses can also be manifested via lower levels of political stability, corruption control, voice and accountability, governmental effectiveness, and the enforcement of the rule of law (Kaufmann et al., 2010). Weak formal institutions increase the level of uncertainties for firms and compel them to rely on informal relationships (with suppliers, customers, and other firms), connections (to the government and to other regulatory officials) and other types of affiliations (e.g., with influential business groups) to safeguard access to critical resources (Khanna \& Palepu, 2000).

We build on institutional theory and utilise the existing literature on EMNEs' internationalisation to develop our hypotheses on the relationship between EMNEs' domestic CSR and their internationalisation scope. When MNEs enter foreign markets, their FSAs developed at home form important sources of their competitive advantages in the host country (Lee \& Rugman, 2012). Earlier studies have noted that despite these FSAs, MNEs suffer from 'liabilities of foreignness', which are defined as the additional costs incurred due to the lack of knowledge of host institutions (Mezias, 2002). When EMNEs (in particular) create foreign subsidiaries, in addition to these liabilities of foreignness, they also suffer from additional 'liabilities of home' (or liabilities of origin), which are defined as 'the disadvantages borne by a firm investing in a foreign country due to the friction caused by the attributes of its home country institutions' (Stevens \& Shenkar, 2012, p. 128). These additional liabilities arise because EMNEs are embedded in weaker home institutions (as described above), which leads to the perception among host country stakeholders that EMNEs are characterised by poorer governance structures and business ethics (Agnihotri \& Bhattacharya, 2019b; Fiaschi et al., 2017; Marano et al., 2017; 
Tashman et al., 2019). At the same time, such liabilities of origin could also stem from EMNEs' relative newness to international business, thereby resulting in the lack of reliable information about EMNEs that causes stakeholders in host countries to develop stereotypical judgements about EMNEs' products (e.g., of being of low quality) and business practices (e.g., of being corrupt) (Marano et al., 2017; Tashman et al., 2019). Volchek et al. (2013), for instance, find that greater levels of political instability and corruption (among other institutional characteristics) in Russia often create barriers for the internationalisation of Russian enterprises.

Due to these extra liabilities, EMNEs face additional barriers to internationalisation; therefore, EMNEs must engage in greater legitimisation processes to reduce these liabilities in both their home and host countries. It is noted that an organisation's legitimacy is evaluated by a broad set of social groups and stakeholders in addition to the government, including interest groups, competitors, the media, non-government organisations (NGOs), financial institutions, employees, customers, elite members of society, and other members of civil society. These actors can also provide or withhold organisations' 'social licence to operate', depending on the degree to which they perceive the organisation as a legitimate and an accepted part of the community (Stevens et al., 2016). MNEs are known to engage in various legitimisation processes to reduce their liabilities of foreignness in a host country, such as by adapting their products and services, hiring local employees, developing local supply chains and engaging in community development (Newenham-Kahindi \& Stevens, 2018).

CSR forms an important means by which to achieve and maintain legitimacy in a global context (Drahos \& Braithwaite, 2001). This is because all firms (including MNEs) have an impact on society. These include both positive impacts, such as the creation of employment opportunities, taxation revenue (to fund vital public services) and the spillover of knowledge and technology to other firms in the local environment, and negative impacts, such as downward pressure on wages, job insecurities, pollution and mismanagement of waste. Therefore, MNEs are pressurised by a variety of institutional actors to undertake business activities in a more responsible manner. While much is known about how MNEs engage in CSR in host countries (especially in developing countries) to secure and maintain their legitimacy (Hah \& Freeman, 2014; Li et al., 2010; Marano \& Tashman, 2012; Shirodkar et al., 2018), surprisingly, little is known about whether EMNEs' domestic CSR can have an impact on their scope of internationalisation.

Within emerging economies, the concept of CSR has been advancing from passive philanthropy to firms' active engagement in socio-developmental activities (Zhao, 2012). Hence, the legitimisation of CSR activities in emerging economies is often associated with firms' engagement in the government's developmental agenda, such as poverty alleviation, corruption control, pollution reduction, and infrastructure development (Zheng et al., 2015). Due to the 'governance gaps' in many emerging economies (Child \& Tsai, 2005; Detomasi, 2007; Zhao, 2012), i.e., failures to protect the rights of citizens and to enforce regulations, CSR in emerging economies is seen, not only as a means of contributing to development but also of taking on government-type responsibilities and providing 'public goods' (Caussat et al., 2019). Overall, in emerging economies, there is a greater need for firms to take on 
a 'political' role and engage in wider governance processes through CSR activities (Krichewsky, 2019; Shirodkar et al., 2018). Subsequently, a greater level of engagement in CSR in emerging economies inadvertently causes firms to interact with a wider variety of stakeholders and to benefit from institutional linkages, which can be leveraged for internationalisation. Therefore, the extent to which EMNEs' domestic CSR facilitates their scope of internationalisation becomes important to study.

\subsection{The Impact of EMNEs' Domestic CSR on Internationalisation}

Based on the background outlined above, in our first hypothesis, we suggest that EMNEs engaging in CSR to a greater extent in their home country are likely to benefit from a greater scope of internationalisation (vis-à-vis expanding within their home base) (Marano et al., 2017).

This is because, first, as previously suggested, engaging more intensively in CSR allows firms in emerging economies to interact with a wider variety of external stakeholders, including policy-makers, NGOs and other regulatory officials, and this improves firms' nonmarket knowledge and capabilities (Zheng et al., 2015). For instance, when setting up a production facility in an emerging market, a firm must pay detailed attention to local nonmarket issues such as labour needs, environmental protection issues, and the responsible use of local natural resources, specifically because the local government and the regulatory authorities may be incapable of dealing with such issues effectively. To do so, firms must embed in local institutions, collaborate with local stakeholders, engage in multistakeholder initiatives (MSIs) and develop specific CSR activities. In this process, firms gain privileged access to government officials (Shirodkar et al., 2018) and build nonmarket capabilities, i.e., capabilities to seek favourable resources from the government. Such nonmarket capabilities form important firm-specific advantages (FSAs) for EMNEs that can be leveraged internationally (Zheng et al., 2015). At the same time, emerging-market governments are increasingly expecting firms to contribute to local developmental issues explicitly, for example, by setting mandates on CSR reporting or expenditure (Yin \& Zhang, 2012). Due to this, varying levels of compliance with CSR expectations can generate varying levels of legitimacy as well as nonmarket advantages (Zheng et al., 2015). China, for instance, requires all its publicly listed firms to report their CSR, whereas in India, it is mandatory for large and medium firms to spend a proportion of their profits on CSR. Therefore, EMNEs that engage in CSR to a greater extent (beyond mandatory requirements) are seen as good corporate citizens by their government and proactively contribute to their government's developmental initiatives (Bhanji \& Oxley, 2013; Matten et al., 2003). Consequently, EMNEs engaging in more intense levels of CSR in their home country are likely to benefit not only from greater legitimacy and reputation but also from nonmarket institutional advantages — such as direct funding, incentives, or other forms of endorsement-when investing overseas (Yan et al., 2018).

Second, greater levels of CSR generate an understanding amongst international stakeholders that, despite the weaker regulations and other institutional voids in emerging economies, as well as the added costs of CSR, the EMNE cares about 
producing high-quality products and taking care of its employees and of the natural environment surrounding them (Yin \& Zhang, 2012). This reduces the EMNE's liabilities of origin, as described previously, and generates greater goodwill and trust among international stakeholders when investing overseas (Marano \& Tashman, 2012; Tashman et al., 2019). For example, Hong and Kim (2017) suggest that when EMNEs invest overseas, their ability to hire talented workers in the host subsidiary can be significantly improved if the EMNE is known to be a responsible citizen. Likewise, studies based on manufacturing firms in China have shown that adopting environmental management systems (such as ISO 14001), as well as other CSR activities, positively impacts their export performance (Chan \& Ma, 2016; Leonidou et al., 2015). Overall, based on these arguments, we hypothesise the following:

Hypothesis 1: Emerging market firms that spend more intensively on CSR activities in their home country are likely to have a greater scope of internationalisation.

\subsection{The Moderating Effect of Government Ownership}

Government or state ownership is common in several emerging economies and has been argued as an important attribute of EMNEs' internationalisation in prior research (Cheung et al., 2015; Cui \& Jiang, 2012; Duanmu, 2014). Within emerging economies, many of the presently private MNEs were state-owned prior to the market-liberalisation era. Even in the current time, the government in many emerging economies continues to hold a full or majority stake in many enterprises (Kalasin et al., 2020; Nuruzzaman et al., 2020; Roper \& Schoenberger-Orgad, 2011; Zhou, 2018). We expect that the utility of domestic CSR in generating both legitimacy and other nonmarket advantages (as argued in the previous section) would be reduced for government-owned EMNEs insofar as their effects on the EMNE's internationalisation are concerned. This is because of the following reasons.

First, state-owned EMNEs have different motivations for internationalisation than private EMNEs. As Ramasamy et al. (2012) suggest, state-owned EMNEs often target politically riskier foreign markets and often have natural resource-seeking motives, whereas private EMNEs are more likely to have market-seeking motives in their international ventures. At the same time, state-owned enterprises (SOEs) do not rely on short-term profitmaking, and their ultimate goal is to provide employment and other public goods. In emerging economies, SOEs are required to take the burden of many governmental responsibilities, such as creating and retaining jobs, upskilling the workforce, absorbing price distortions and restraining disproportionate executive compensation (Cheung et al., 2015). For example, Oil and Natural Gas Corporation (ONGC), a leading Indian MNE that has investments in many foreign countries, provides its employees and their families with free on-site medical facilities and subsidised housing, alongside various other welfare benefits. At the same time, ONGC, through its CSR, also contributes to other 'national issues' in India, such as rural development, women's empowerment and sponsoring higher education for poor students (Banerjee, 2020). SOEs' social and environmental actions are thus better aligned with national policies, which leads them to be better embedded 
in the home country's institutional system (Khalid et al., 2021), although they also have to explicitly report their CSR due to pressure from the government (Li \& Belal, 2018; Zhu et al., 2016). However, as Shahab et al. (2019) find, CSR quality ratings have a lesser effect on SOEs' financial distress than that of their private counterparts. In sum, due to their distinct motives in international expansion and their rather 'implicit' CSR (Matten \& Moon, 2008), state-owned EMNEs enjoy greater legitimacy among external stakeholders than their private counterparts and thus face fewer liabilities of origin when investing overseas.

Second, SOEs have distinct 'nonmarket advantages' that private firms would have to gain through their strategic CSR or through the development of political connections, as argued previously (Husted \& Allen, 2007; Wang et al., 2018). Deng et al. (2018), for instance, emphasise that SOEs have 'ascribed' political connections due to their long history of working with the government and its developmental initiatives. Due to this, there is less utility of investing extensively in CSR to benefit from the legitimisation advantages and developing the nonmarket capabilities necessary to invest abroad. Although extra spending on CSR can complement SOEs' 'ascribed' nonmarket advantages, there would be opportunity costs in doing so. Investing in CSR and issuing CSR reports are both costly, and for SOEs in emerging economies, there is little 'business case' in doing so to gain the same strategic advantages as accrued by private firms (Wang et al., 2018; Yin \& Zhang, 2012). For example, as a result of their ascribed nonmarket advantages, if a governmentor state-owned EMNE is interested in internationalisation, it can secure funding to do so more easily from government sources (Cui \& Jiang, 2012; Zhou, 2018) and benefit from reduced levels of risk in the foreign host environment (Duanmu, 2014). Overall, based on these arguments, we suggest the following:

Hypothesis 2: The positive effect of domestic CSR intensity on internationalisation is reduced if the emerging market firm is government-owned.

\subsection{The Moderating Effect of the Type of Host Market}

Finally, we suggest that the liabilities of origin faced by EMNEs would vary depending on the host country that they target for internationalisation. Studies based on institutional theory suggest that emerging and developed countries differ significantly with regard to both regulative and normative institutional forces (Chao \& Kumar, 2010; Eden \& Miller, 2004; Gaur \& Lu, 2007; Salomon \& Wu, 2012; Shirodkar \& Konara, 2017). Such differences are likely to impact EMNEs' liabilities of origin and hence the utility of domestic CSR in reducing these liabilities.

When EMNEs invest in developed countries, due to the greater institutional differences compared to when investing in other emerging economies, EMNEs will not only suffer from liabilities of origin (as argued previously) but also from greater 'liabilities of foreignness' (Zaheer, 1995), and the need to develop legitimacy would also be greater. Recent studies on the asymmetric effect of institutional distance (Hernández \& Nieto, 2015; Hernández et al., 2018) suggest that EMNEs would have to develop greater levels of legitimacy when investing in developed countries due to the needs of not only 'learning' about the host country context but also 'unlearning' some of the aspects 
of their home institutions, such as, for instance, corrupt practices that may have been 'imprinted' in them (Konara \& Shirodkar, 2018). Overall, in developed countries, people's perceptions of a firm's concern for the wider society influence their judgements about the firm to a greater extent than in emerging economies (Fombrun \& Shanley, 1990). We therefore expect that greater levels of domestic CSR can be more instrumental for EMNEs when investing in developed countries (vis-à-vis in other emerging economies). Prior studies have found that EMNEs use CSR in strategic ways to enter developed countries and to satisfy their host government and other stakeholders. For instance, many EMNEs issue CSR reports when their investments are specifically directed towards countries where there are active press and watchdog organisations; in such countries, EMNEs may use their CSR reporting to enhance their legitimacy (Fiaschi et al., 2017). Overall, based on this, we propose the following hypothesis:

Hypothesis 3a: The positive effect of domestic CSR on internationalisation is greater when emerging market firms are internationalising into developed countries than in other emerging economies.

Although we expect (above) that EMNEs' domestic CSR will impact their scope of internationalisation differently when they invest in developed countries compared to other emerging economies, this expectation offers an incomplete picture. When investing in other emerging economies, EMNEs have more competitive advantages and fewer transaction and coordination costs when they invest in host countries with relatively weaker host institutions than their home countries (Wright et al., 2005). As emerging economies are heterogeneous in their institutional characteristics, we further expect that the effect of EMNEs' domestic CSR on their internationalisation to other emerging economies will vary depending on whether the targeted emerging economy has stronger institutions than the EMNE's home country. This is because our previous argument relating to liabilities of origin (Marano \& Kostova, 2016; Marano et al., 2017) is also applicable when EMNEs are investing in other emerging economies with stronger institutions. Emerging economies with stronger institutions will emphasise more on the CSR standards of EMNEs investing in their market than emerging economies with relatively weaker institutions. Based on this, we propose the following:

Hypothesis 3b: The positive effect of EMNEs' domestic CSR on internationalisation is greater when emerging market firms are internationalising into other emerging host countries with relatively stronger institutions compared to in their home country.

Figure 1 summarises our theoretical framework.

\section{Methodology}

\subsection{Research Context}

To test our hypotheses, we focus on the context of India, which provides us with an ideal context for the following reasons. First, India is considered one of the major 


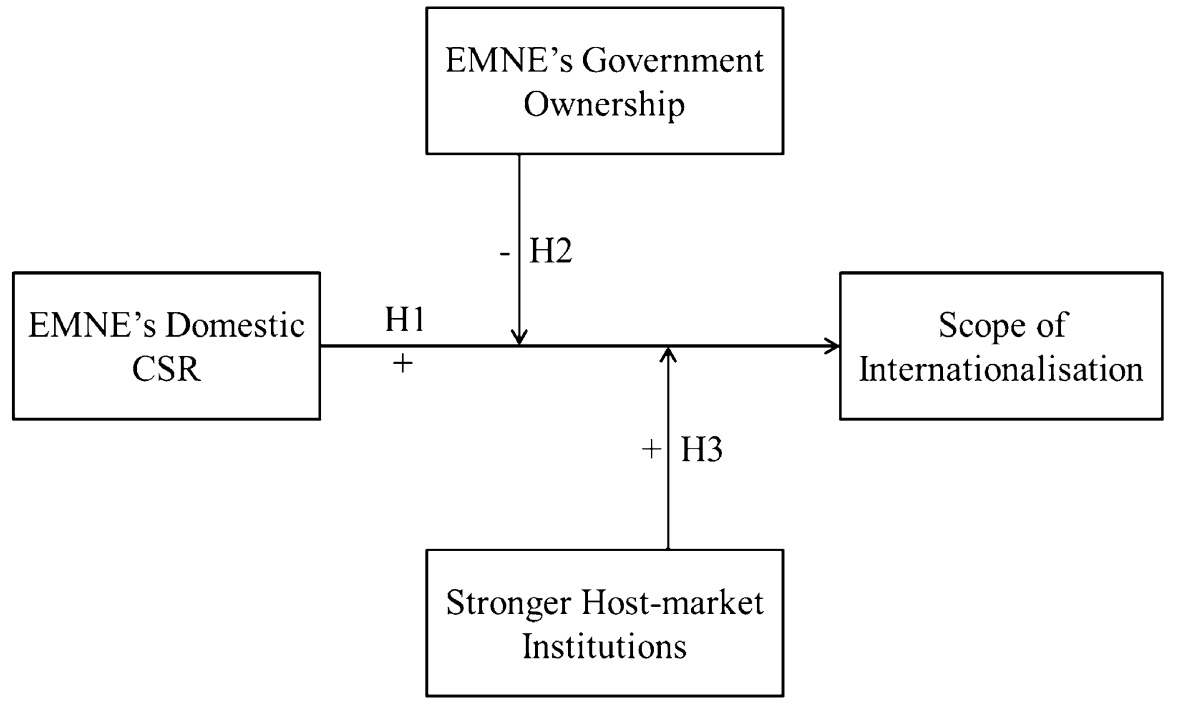

Fig. 1 Theoretical framework

emerging economies, and Indian multinationals are increasingly investing in various foreign markets (Bangara et al., 2012; Chittoor et al., 2015). Over the past decade, there has been an exponential rise in overseas investment by Indian firms (Saikia et al., 2020). Based on a recent report by the Reserve Bank of India, the outward FDI from India increased from US\$ 6.6 billion in 2017 to US\$ 13 billion in 2020 (RBI, 2020). In 2015, India stood as the sixth-largest outward investor among the emerging economies, and the overall growth of Indian OFDI over the past decade has been comparable to many other emerging economies, such as Brazil, Mexico, South Africa, Malaysia and Chile (Perea \& Stephenson, 2018). Indian companies are also known to be important investors in both developed and developing markets. For instance, India is the second largest foreign investor in the United Kingdom (the largest being the United States) (Economic-Times, 2020). Broadly, the United States and Europe form important developed markets for Indian FDI, whereas the South Asian and East African markets form the major developing markets (Chaudhry et al., 2018).

Second, regulatory pressures on CSR are growing in India. As mentioned earlier, a CSR expenditure policy (under the Companies Act 2013) was implemented in India in 2014 and requires medium-to-large companies operating in India to spend $2 \%$ of their average net profits (over the past 3 years) on socioeconomic development activities. These activities must fall under a broad set of themes specified under schedule VII of the Companies Act. The CSR law also requires companies to set up a CSR committee, internally monitor and ensure compliance, and report on their CSR in their annual reports and on their website. Penalties are applied only when companies neither comply with the regulation nor explain reasons for being unable to do so. However, the government has been trying to become more stringent about noncompliance with regard to the 
minimum expenditure. Following the implementation of the law in 2014, Indian companies spent approximately US\$ 1.3 billion on CSR in the first year, and in 2017-2018, the figure had risen to nearly US\$1.8 billion (National-CSR-Portal, 2020). A recent study, however, found that there is more severe underexpenditure on CSR by most firms than would be expected based on firms' average net income (Marques \& Srinivasan, 2018). Additionally, many companies have been found to have merely provided reasons for a shortfall in their spending or for not spending their entire 2\% on CSR (Tendolkar, 2019). Thus, it has been argued that although the CSR law might have generated more participation in terms of CSR, most of the CSR expenditure in the current time is not entirely driven by the government mandate (Subramaniam et al., 2017), with some companies spending more and others spending less than the required amount based on individual circumstances. While discussing the rationale behind CSR law, the report of a high-level committee set up to assess the law suggests that the aim of the law has been to generate an enabling environment for corporations to perform CSR while contributing to the developmental goals of the nation. As such, the motivation of the CSR law to improve the enforcement of existing laws and regulations regarding various developmental issues (such as reducing pollution, corruption, etc.) has been reflected in a number of recent studies (Krichewsky, 2017, 2019).

\subsection{Sample and Data Collection}

We obtained our data from two sources. First, we obtained a list of firms' CSR expenditures from the Indian government's national CSR portal (National-CSRPortal, 2020). The website reports how much various companies have spent on CSR and where their expenditures have been distributed. We obtained the CSR expenditures of Indian firms for 2018, and this provided us with an initial list of more than 20,000 firms, many of which reported zero CSR expenditures. The number of firms that spent positively on CSR was 8385, starting from a minimum of INR 100,000 (approximately US\$1355) up to a maximum of INR 7,450,400,000 (US\$ 100,951,206) spent by Reliance Industries Limited.

Following this, we obtained the rest of our firm-level data from Bureau Van Dijk's Orbis database. Orbis provides data for more than 2 million companies operating in India. Since we were interested in companies that were involved in internationalisation via foreign direct investment, we searched for all Indian companies having at least one foreign subsidiary (with a minimum shareholding of 10\%) within Orbis. This resulted in a list of 4687 firms. We then matched this with the CSR data that we had obtained from the National CSR Portal as described above, which resulted in a matched sample of 1621 companies for which we could obtain company data from Orbis, as well as those that had reported their CSR expenditure. We then downloaded firm-level data for these companies from Orbis. After cleaning the data for inconsistencies and taking into account missing values, our final sample was reduced to 686 firms. 


\subsection{Measures}

Our dependent variable is emerging market firms' scope of internationalisation. We measured this using the ratio of firms' foreign subsidiaries to total subsidiaries (RFSTS). Such scope metrics of internationalisation have been suggested and used by various studies in the past (Caligiuri et al., 2004; Kedia \& Mozumdar, 2003; Mohr \& Batsakis, 2019; Rugman \& Oh, 2011). The scope metric allows us to understand the extent to which the firm is likely to set up a subsidiary in a foreign market versus in its home market. While various measures of internationalisation exist, such as export revenues and the ratio of foreign to total sales, we suggest that our measure enabled us to effectively measure the extent of emerging market firms' FDI-based internationalisation, which is indicative of EMNEs' greater levels of commitment to foreign markets. We also counted the number of developed and emerging countries in which each of the firms in our list had foreign subsidiaries. The classification of developed and emerging countries was based on the Organisation for Economic Co-operation and Development (OECD). This led us to our two variables, namely, the ratio of foreign subsidiaries in developed countries to total subsidiaries (RFDSTS) and the ratio of foreign subsidiaries in emerging economies to total subsidiaries (RFESTS). Furthermore, among the emerging economies, we counted the number of foreign subsidiaries located in countries with institutionally stronger countries compared to India. To measure the quality of institutions, we used the Worldwide Governance Indicators (WGI), following prior studies (Dutta et al., 2016; Wu et al., 2016). The WGI project scores countries on six dimensions related to institutional quality. These dimensions are voice and accountability, political stability (and absence of violence), government effectiveness, regulatory quality, rule of law, and control of corruption (Kaufmann et al., 2010). We took the composite score of these indicators to calculate the ratio of foreign subsidiaries in emerging economies with better institutions (than India) to total subsidiaries in emerging economies (RFSBITSE).

Our key independent variable is CSR intensity. We measured this as the ratio of firms' CSR expenditure to their total assets. The intensity of CSR is a popular measure used in past studies on CSR, although prior studies have focused on the intensity of CSR communication obtained from firms' CSR reports (Lattemann et al., 2009; Li et al., 2010). As Indian firms are required to spend a proportion of their net profits on CSR (as described previously), this enabled us to use their CSR expenditure. Recent studies have shown that our measure allows us to gauge the extent of firms' engagement with various stakeholders (especially the government) and to gain legitimacy by focusing on some unique areas of social development (Aswani et al., 2020; Mukherjee \& Bird, 2016). However, given that CSR expenditure in India is largely driven by the government mandate, to assess the validity of our measure, we used an alternative measure of CSR intensity as part of our robustness tests.

We also controlled for various other factors that have been argued to impact the internationalisation of emerging market firms in the past (Chittoor et al., 2015; Kumar et al., 2012). These include firm-level factors such as firm size, which was measured by operating revenue (or turnover); firm age, which was measured by their age since their year of incorporation; firm leverage, which was measured by firms' 
long-term debt by the total assets; firms' profitability, which was measured by their return on equity; top management team size, which was measured by the number of directors and managers; a dummy variable, namely, government owned, which indicated whether the government has a full or majority stake in the firm; a dummy variable, namely, group affiliated, which indicated whether the firm is affiliated with a business group; and a dummy variable which indicated whether the firm is family owned. We also controlled for some characteristics of the business and industry environment, which have been argued to improve the internationalisation prospects of firms. These included a dummy variable, namely, city based, which indicated whether the firm is based in a major Indian city, i.e., Mumbai, New Delhi, Chennai, Kolkata, Pune, Hyderabad or Bangalore. Finally, we used industry dummies to control for three major industries, namely, manufacturing, high-tech services and lowtech services, as these form the major industries that are internationally oriented in the context of India. Table 1 provides a summary of our variables, their measures and their data sources.

Table 2 provides a more detailed description of our sampled firms by the industry and the averages in CSR expenditure and in their internationalisation levels. It can be seen that on average, firms in the high-tech industry in India spend the most on CSR $(\$ 1,778,401$ in 2018) and have the highest average in terms of the number of foreign subsidiaries (10.08) in developed countries. Firms in the manufacturing industry also spend highly on CSR (average $\$ 818,581$ in 2018) but seem to invest in both developed countries and emerging economies in nearly equal proportions.

\section{Results}

Our descriptive statistics and correlations are presented in Table 3. As we do not see any high correlations between the independent and control variables, we expect that there were no multicollinearity problems at this point; however, we also verified this by checking for the variable inflation factor (VIF) in our regressions (Schroeder et al., 1990).

The OLS regression results are presented in Table 4. In Model 1, we added our main independent variable, namely, CSR intensity. In Model 2, we tested for the moderating effect of government ownership by using the interaction term CSR intensity $\times$ Government owned. Furthermore, in Models 3, 4 and 5, we changed the dependent variable to RFDSTS, RFESTS and RFSBITSE, respectively, to test for the effect of CSR intensity on internationalisation into developed versus emerging economies and into emerging economies with better institutions.

In hypothesis 1, we argued for a positive relationship between domestic CSR intensity and EMNEs' scope of internationalisation. The results from the OLS estimator (Table 4, Model 1) show a positive and statistically significant effect of CSR intensity on RFSTS ( $\beta=0.105, p=0.007)$, thereby strongly supporting hypothesis 1 . In hypothesis 2, we expected that the effect of domestic CSR intensity on EMNEs' scope of internationalisation would be reduced if the firm is government owned (fully or by majority). The results from the OLS estimator (Table 4, Model 2) show a negative and statistically significant coefficient of CSR intensity $\times$ Government 


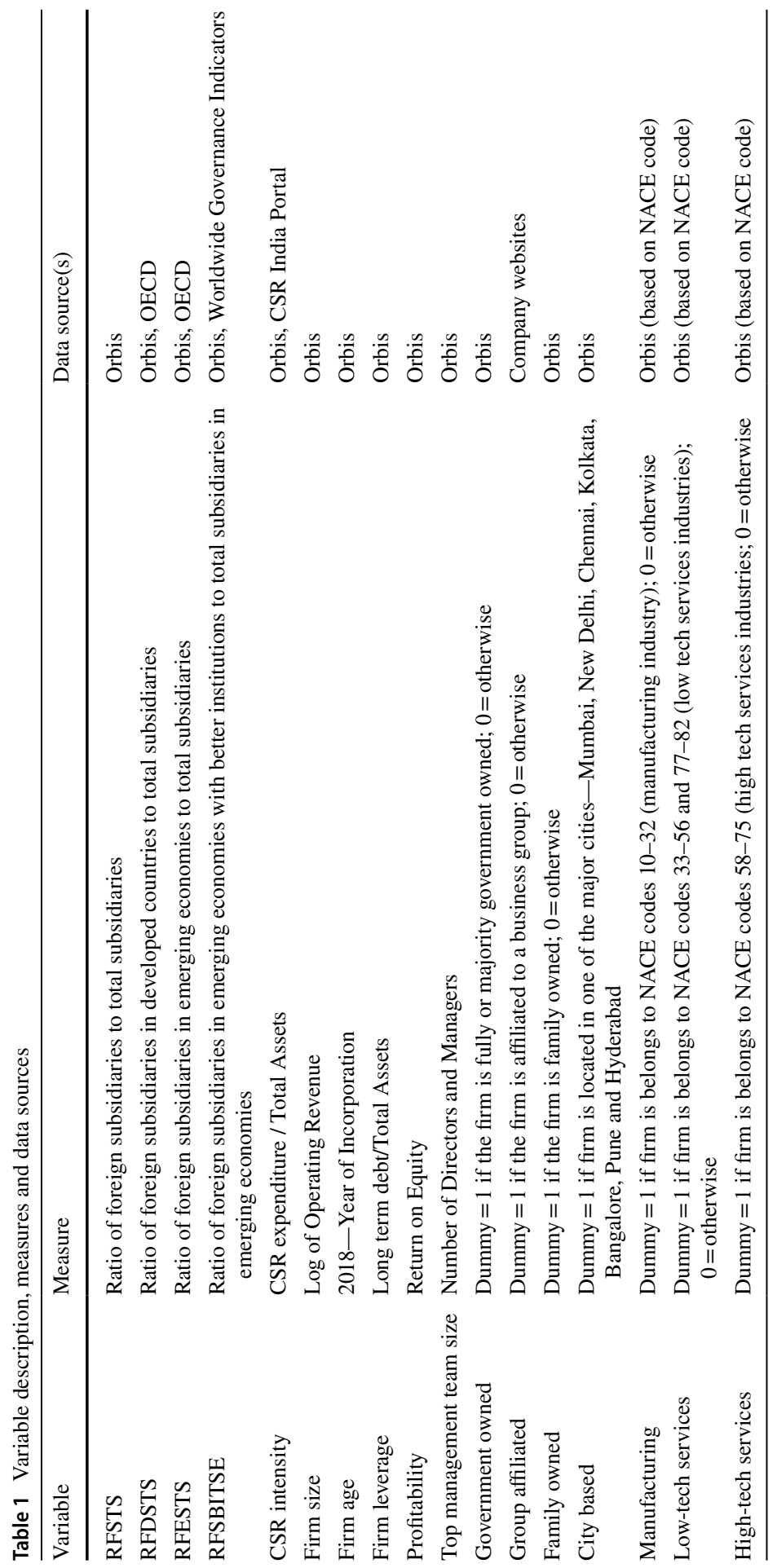




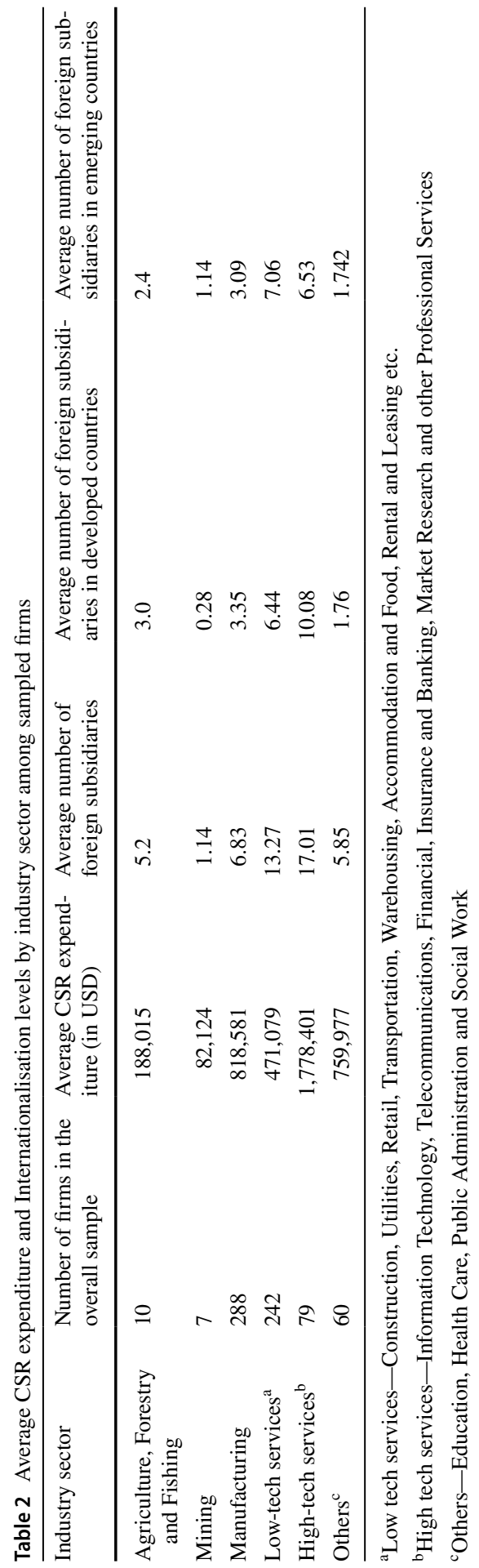




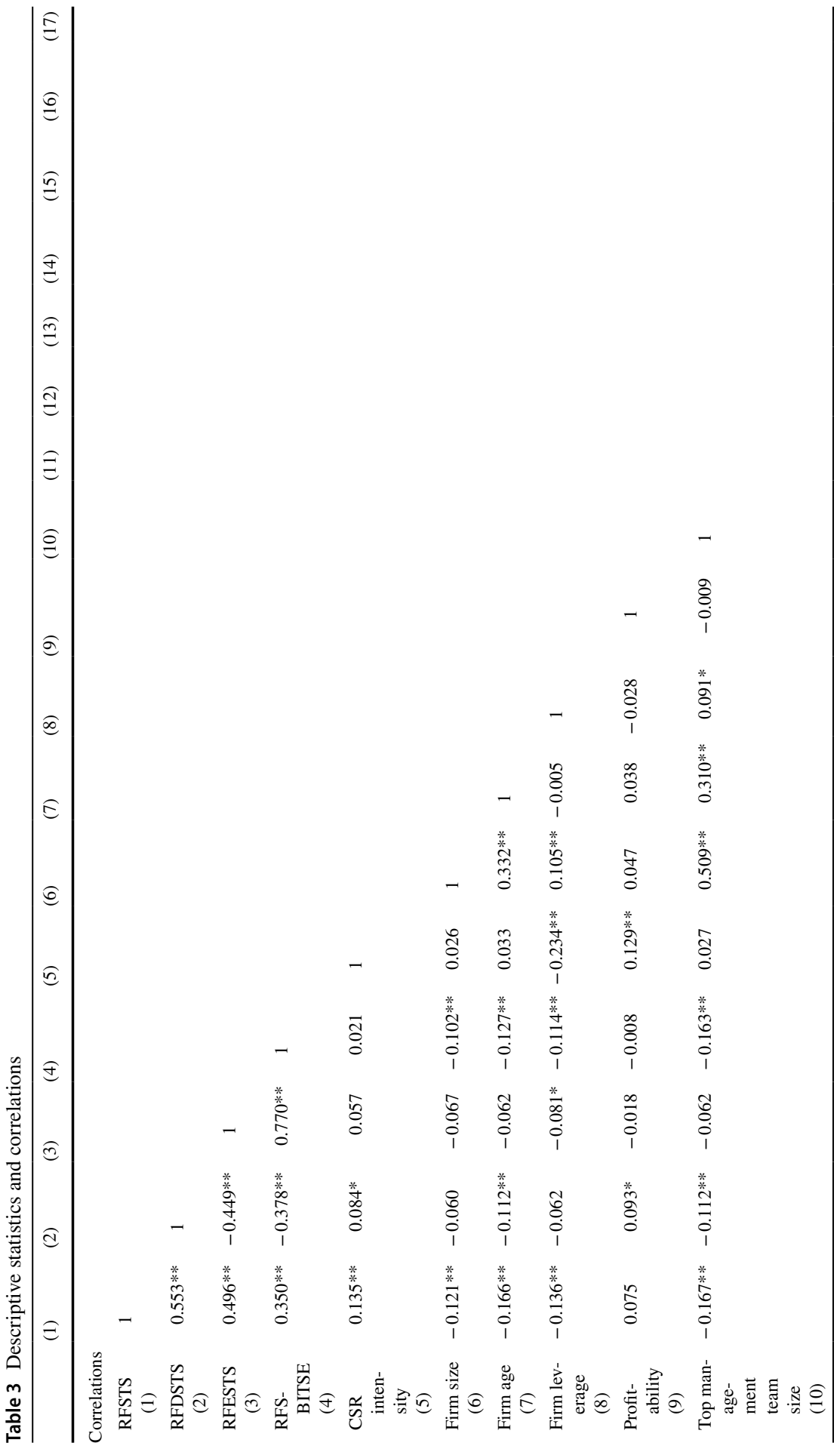




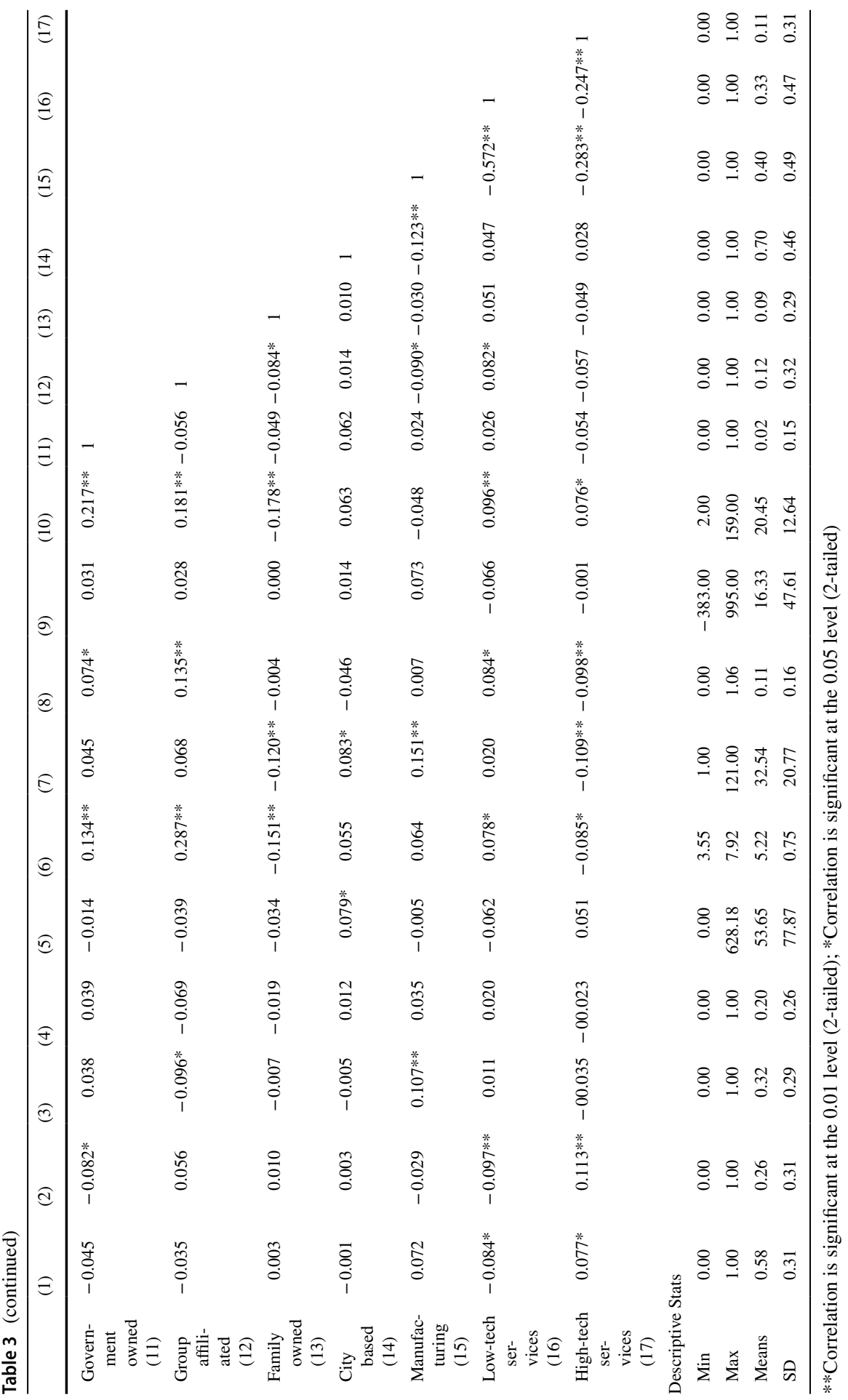


Table 4 OLS regression results

\begin{tabular}{|c|c|c|c|c|c|}
\hline & $\begin{array}{l}\text { Model } 1 \\
\text { DV = RFSTS }\end{array}$ & $\begin{array}{l}\text { Model } 2 \\
\text { DV = RFSTS }\end{array}$ & $\begin{array}{l}\text { Model } 3 \\
\text { DV = RFDSTS }\end{array}$ & $\begin{array}{l}\text { Model } 4 \\
\text { DV = RFESTS }\end{array}$ & $\begin{array}{l}\text { Model } 5 \\
\text { DV = RFSBITSE }\end{array}$ \\
\hline CSR intensity & $\begin{array}{l}0.105 * * * \\
(0.000) \\
0.007\end{array}$ & $\begin{array}{l}0.117 * * * \\
(0.000) \\
0.003\end{array}$ & $\begin{array}{l}0.072 * \\
(0.000) \\
0.067\end{array}$ & $\begin{array}{l}0.037 \\
(0.000) \\
0.347\end{array}$ & $\begin{array}{l}-0.011 \\
(0.001) \\
0.802\end{array}$ \\
\hline $\begin{array}{l}\text { CSR intensity } \times \text { Gov- } \\
\text { ernment owned }\end{array}$ & & $\begin{array}{l}-0.106^{* *} \\
(0.001) \\
0.018\end{array}$ & & & \\
\hline Firm size & $\begin{array}{l}-0.018 \\
(0.019) \\
0.698\end{array}$ & $\begin{array}{l}-0.022 \\
(0.019) \\
0.639\end{array}$ & $\begin{array}{l}-0.003 \\
(0.019) \\
0.943\end{array}$ & $\begin{array}{l}-0.016 \\
(0.018) \\
0.740\end{array}$ & $\begin{array}{l}0.072 \\
(0.117) \\
0.167\end{array}$ \\
\hline Firm age & $\begin{array}{l}-0.148 * * * \\
(0.001) \\
0.000\end{array}$ & $\begin{array}{l}-0.150^{* * * *} \\
(0.001) \\
0.000\end{array}$ & $\begin{array}{l}-0.080 * \\
(0.001) \\
0.053\end{array}$ & $\begin{array}{l}-0.075 * \\
(0.001) \\
0.075\end{array}$ & $\begin{array}{l}-0.014 \\
(0.004) \\
0.769\end{array}$ \\
\hline Firm leverage & $\begin{array}{l}-0.096^{* *} \\
(0.092) \\
0.015\end{array}$ & $\begin{array}{l}-0.100 * * \\
(0.092) \\
0.011\end{array}$ & $\begin{array}{l}-0.031 \\
(0.092) \\
0.442\end{array}$ & $\begin{array}{l}-0.071 * \\
(0.088) \\
0.079\end{array}$ & $\begin{array}{l}-0.021 \\
(0.572) \\
0.639\end{array}$ \\
\hline Profitability & $\begin{array}{l}0.053 \\
(0.000) \\
0.155\end{array}$ & $\begin{array}{l}0.053 \\
(0.000) \\
0.154\end{array}$ & $\begin{array}{l}0.079 * * \\
(0.000) \\
0.038\end{array}$ & $\begin{array}{l}-0.026 \\
(0.000) \\
0.499\end{array}$ & $\begin{array}{l}0.061 \\
(0.001) \\
0.150\end{array}$ \\
\hline $\begin{array}{l}\text { Top management } \\
\text { team size }\end{array}$ & $\begin{array}{l}-0.126^{* * * *} \\
(0.001) \\
0.006\end{array}$ & $\begin{array}{l}-0.120^{* * * *} \\
(0.001) \\
0.009\end{array}$ & $\begin{array}{l}-0.093 * * \\
(0.001) \\
0.047\end{array}$ & $\begin{array}{l}-0.037 \\
(0.001) \\
0.428\end{array}$ & $\begin{array}{l}0.008 \\
(0.007) \\
0.883\end{array}$ \\
\hline Government owned & $\begin{array}{l}0.001 \\
(0.077) \\
0.984\end{array}$ & $\begin{array}{l}0.061 \\
(0.093) \\
0.186\end{array}$ & $\begin{array}{l}-0.047 \\
(0.077) \\
0.228\end{array}$ & $\begin{array}{l}0.051 \\
(0.074) \\
0.199\end{array}$ & $\begin{array}{l}-0.067 \\
(0.543) \\
0.125\end{array}$ \\
\hline Group affiliated & $\begin{array}{l}0.036 \\
(0.039) \\
0.371\end{array}$ & $\begin{array}{l}0.037 \\
(0.038) \\
0.354\end{array}$ & $\begin{array}{l}0.084 * * \\
(0.038) \\
0.039\end{array}$ & $\begin{array}{l}-0.050 \\
(0.037) \\
0.221\end{array}$ & $\begin{array}{l}0.089 * \\
(0.241) \\
0.053\end{array}$ \\
\hline Family owned & $\begin{array}{l}-0.009 \\
(0.042) \\
0.807\end{array}$ & $\begin{array}{l}-0.009 \\
(0.041) \\
0.819\end{array}$ & $\begin{array}{l}0.012 \\
(0.041) \\
0.760\end{array}$ & $\begin{array}{l}-0.022 \\
(0.040) \\
0.565\end{array}$ & $\begin{array}{l}0.024 \\
(0.267) \\
0.575\end{array}$ \\
\hline City based & $\begin{array}{l}0.012 \\
(0.026) \\
0.746\end{array}$ & $\begin{array}{l}0.008 \\
(0.026) \\
0.834\end{array}$ & $\begin{array}{l}0.003 \\
(0.026) \\
0.943\end{array}$ & $\begin{array}{l}0.010 \\
(0.024) \\
0.791\end{array}$ & $\begin{array}{l}0.064 \\
(0.161) \\
0.128\end{array}$ \\
\hline Manufacturing & $\begin{array}{l}0.165 * * * \\
(0.035) \\
0.003\end{array}$ & $\begin{array}{l}0.158 * * * \\
(0.035) \\
0.004\end{array}$ & $\begin{array}{l}-0.040 \\
(0.035) \\
0.468\end{array}$ & $\begin{array}{l}0.219 * * * \\
(0.033) \\
0.000\end{array}$ & $\begin{array}{l}-0.008 \\
(0.226) \\
0.903\end{array}$ \\
\hline Low-tech services & $\begin{array}{l}0.072 \\
(0.036) \\
0.171\end{array}$ & $\begin{array}{l}0.069 \\
(0.035) \\
0.189\end{array}$ & $\begin{array}{l}-0.071 \\
(0.035) \\
0.189\end{array}$ & $\begin{array}{l}0.152 * * * \\
(0.034) \\
0.005\end{array}$ & $\begin{array}{l}0.019 \\
(0.228) \\
0.759\end{array}$ \\
\hline High-tech services & $\begin{array}{l}0.113 * * \\
(0.045) \\
0.014\end{array}$ & $\begin{array}{l}0.109 * * \\
(0.045) \\
0.018\end{array}$ & $\begin{array}{l}0.073 \\
(0.045) \\
0.116\end{array}$ & $\begin{array}{l}0.045 \\
(0.043) \\
0.342\end{array}$ & $\begin{array}{l}0.200 * * * \\
(0.289) \\
0.000\end{array}$ \\
\hline $\mathrm{N}$ & 686 & 686 & 686 & 686 & 553 \\
\hline $\mathrm{R}$ square & .090 & .098 & .060 & .045 & .067 \\
\hline
\end{tabular}

Standard errors in parentheses; $\mathrm{p}$-values in italics *** $\mathrm{p}<0.01, * * \mathrm{p}<0.05, * \mathrm{p}<0.10$ 
owned on RFSTS $(\beta=-0.106, p=0.018)$. This outcome is indicative that hypothesis 2 has been supported. In hypothesis $3 \mathrm{a}$, we argued that the effect of domestic CSR on EMNEs' scope of internationalisation would be more pronounced when these firms internationalise into developed countries versus when they internationalise into emerging economies. The results from the OLS estimator (Table 4, Model 3) show a positive and statistically significant coefficient of CSR intensity on RFDSTS ( $\beta=0.072, p=0.067)$; however, this coefficient is significant at the $10 \%$ level. At the same time, the OLS estimator (Table 4, Model 4) shows that the effect of CSR intensity on RFESTS is insignificant. Overall, this renders weak support for hypothesis 3a. Finally, in hypothesis $3 b$, we argued that domestic CSR would increase the scope of internationalisation to other emerging economies with relatively better institutions. The OLS estimator (Table 4, Model 5) shows that the effect of CSR intensity on RFSBITSE is insignificant, thereby rejecting hypothesis $3 \mathrm{~b}$. To test this hypothesis further, we carried out a post hoc analysis in which we calculated RFSBITSE using each of the six dimensions of the world governance indicators and reran the regressions. However, the effect of CSR intensity on RFSBITSE remained insignificant, ${ }^{1}$ which is consistent with the effect using the composite score of institutional quality.

Some of our control variables also present some interesting results. We can see that firm age is negatively associated with internationalisation. This shows that newer Indian firms show a much greater propensity to invest overseas, whereas older and well-established firms are more likely to invest domestically. Likewise, firm leverage and top management team size are also consistently negatively associated with the scope of internationalisation. We also see that group-affiliated Indian firms are positively associated with internationalisation into developed countries. Finally, we see that Indian firms in the manufacturing and high-tech services sectors have a greater propensity to invest in foreign markets. We also see that among firms in the manufacturing and low-tech services sectors, there is a greater propensity to invest in other emerging economies vis-à-vis developed countries.

In addition to the above analyses, we also conducted robustness tests. First, since our main measure of CSR is calculated based on the CSR expenditure reported by firms and because this expenditure is driven by the Indian CSR mandate that requires firms to invest $2 \%$ of their average net income over the past three years into CSR, we checked for the possibility of whether the mandate itself could have an impact on CSR and hence on the internationalisation of Indian firms. To address this issue, we calculated each firm's discretionary CSR expenditure, which takes the value of zero if the firm spent less than or equal to the expected CSR amount as per the mandate; otherwise, it takes the difference between the actual (i.e., reported) and expected CSR expenditure. We then calculated discretionary CSR intensity by dividing discretionary CSR expenditure by total assets. This process, however, resulted in a large number of firms having a zero value; thus, we reran the regressions using only the subset of firms $(\mathrm{N}=112)$ that had a positive value of discretionary CSR intensity. The results are presented in Table 5. We found that this variable has a

\footnotetext{
${ }^{1}$ For brevity, the results of this post hoc test are excluded from the paper but can be provided upon request.
} 
Table 5 OLS regression results (with discretionary CSR)

\begin{tabular}{|c|c|c|c|c|c|}
\hline & $\begin{array}{l}\text { Model } 6 \\
\text { DV = RFSTS }\end{array}$ & $\begin{array}{l}\text { Model } 7 \\
\text { DV = RFSTS }\end{array}$ & $\begin{array}{l}\text { Model } 8 \\
\text { DV = RFDSTS }\end{array}$ & $\begin{array}{l}\text { Model } 9 \\
\text { DV=RFESTS }\end{array}$ & $\begin{array}{l}\text { Model } 10 \\
\text { DV = RFSBITSE }\end{array}$ \\
\hline $\begin{array}{l}\text { Discretionary CSR } \\
\quad \text { intensity }\end{array}$ & $\begin{array}{l}0.264 * * * \\
(0.046) \\
0.006\end{array}$ & $\begin{array}{l}0.265 * * * \\
(0.046) \\
0.006\end{array}$ & $\begin{array}{l}0.253 * * * \\
(0.039) \\
0.008\end{array}$ & $\begin{array}{l}0.052 \\
(0.044) \\
0.593\end{array}$ & $\begin{array}{l}0.073 \\
(0.169) \\
0.534\end{array}$ \\
\hline $\begin{array}{l}\text { Discretionary CSR } \\
\text { intensity } \times \text { Govern- } \\
\text { ment owned }\end{array}$ & & $\begin{array}{l}-0.010 \\
(0.002) \\
0.932\end{array}$ & & & \\
\hline Firm size & $\begin{array}{l}0.050 \\
(0.048) \\
0.669\end{array}$ & $\begin{array}{l}0.049 \\
(0.049) \\
0.676\end{array}$ & $\begin{array}{l}0.065 \\
(0.041) \\
0.580\end{array}$ & $\begin{array}{l}-0.006 \\
(0.047) \\
0.963\end{array}$ & $\begin{array}{l}0.018 \\
(0.170) \\
0.902\end{array}$ \\
\hline Firm age & $\begin{array}{l}-0.270^{* *} \\
(0.002) \\
0.010\end{array}$ & $\begin{array}{l}-0.270 * * \\
(0.002) \\
0.011\end{array}$ & $\begin{array}{l}-0.199 * \\
(0.001) \\
0.056\end{array}$ & $\begin{array}{l}-0.108 \\
(0.001) \\
0.315\end{array}$ & $\begin{array}{l}-0.146 \\
(0.005) \\
0.242\end{array}$ \\
\hline Firm leverage & $\begin{array}{l}-0.020 \\
(0.240) \\
0.837\end{array}$ & $\begin{array}{l}-0.019 \\
(0.241) \\
0.840\end{array}$ & $\begin{array}{l}0.172 * \\
(0.204) \\
0.071\end{array}$ & $\begin{array}{l}-0.179 * \\
(0.232) \\
0.071\end{array}$ & $\begin{array}{l}-0.018 \\
(0.923) \\
0.882\end{array}$ \\
\hline Profitability & $\begin{array}{l}0.142 \\
(0.002) \\
0.135\end{array}$ & $\begin{array}{l}0.143 \\
(0.002) \\
0.136\end{array}$ & $\begin{array}{l}0.255^{* * * *} \\
(0.002) \\
0.008\end{array}$ & $\begin{array}{l}-0.081 \\
(0.002) \\
0.408\end{array}$ & $\begin{array}{l}0.046 \\
(0.007) \\
0.696\end{array}$ \\
\hline $\begin{array}{l}\text { Top management } \\
\text { team size }\end{array}$ & $\begin{array}{l}-0.042 \\
(0.002) \\
0.717\end{array}$ & $\begin{array}{l}-0.040 \\
(0.002) \\
0.736\end{array}$ & $\begin{array}{l}0.084 \\
(0.002) \\
0.469\end{array}$ & $\begin{array}{l}-0.122 \\
(0.002) \\
0.311\end{array}$ & $\begin{array}{l}0.228 \\
(0.007) \\
0.101\end{array}$ \\
\hline Government owned & $\begin{array}{l}-0.018 \\
(0.162) \\
0.860\end{array}$ & $\begin{array}{l}-0.013 \\
(0.191) \\
0.916\end{array}$ & $\begin{array}{l}-0.170 \\
(0.138) \\
0.102\end{array}$ & $\begin{array}{l}0.136 \\
(0.157) \\
0.206\end{array}$ & $\begin{array}{l}-0.217 * \\
(0.531) \\
0.090\end{array}$ \\
\hline Group affiliated & $\begin{array}{l}0.074 \\
(0.113) \\
0.474\end{array}$ & $\begin{array}{l}0.074 \\
(0.113) \\
0.479\end{array}$ & $\begin{array}{l}0.044 \\
(0.096) \\
0.669\end{array}$ & $\begin{array}{l}0.039 \\
(0.109) \\
0.715\end{array}$ & $\begin{array}{l}0.108 \\
(0.390) \\
0.397\end{array}$ \\
\hline Family owned & $\begin{array}{l}-0.075 \\
(0.091) \\
0.418\end{array}$ & $\begin{array}{l}-0.075 \\
(0.091) \\
0.422\end{array}$ & $\begin{array}{l}0.043 \\
(0.077) \\
0.642\end{array}$ & $\begin{array}{l}-0.120 \\
(0.088) \\
0.213\end{array}$ & $\begin{array}{l}-0.002 \\
(0.347) \\
0.983\end{array}$ \\
\hline City based & $\begin{array}{l}0.264 * * * \\
(0.069) \\
0.005\end{array}$ & $\begin{array}{l}0.263 * * * \\
(0.070) \\
0.007\end{array}$ & $\begin{array}{l}0.024 \\
(0.059) \\
0.800\end{array}$ & $\begin{array}{l}0.262 \text { *** } \\
(0.067) \\
0.008\end{array}$ & $\begin{array}{l}-0.049 \\
(0.255) \\
0.660\end{array}$ \\
\hline Manufacturing & $\begin{array}{l}0.117 \\
(0.085) \\
0.359\end{array}$ & $\begin{array}{l}0.117 \\
(0.085) \\
0.361\end{array}$ & $\begin{array}{l}-0.289 * * \\
(0.072) \\
0.025\end{array}$ & $\begin{array}{l}0.390 * * * \\
(0.082) \\
0.004\end{array}$ & $\begin{array}{l}-0.324 * \\
(0.353) \\
0.077\end{array}$ \\
\hline Low-tech services & $\begin{array}{l}-0.009 \\
(0.086) \\
0.944\end{array}$ & $\begin{array}{l}-0.008 \\
(0.087) \\
0.949\end{array}$ & $\begin{array}{l}-0.236^{*} \\
(0.073) \\
0.058\end{array}$ & $\begin{array}{l}0.207 \\
(0.083) \\
0.108\end{array}$ & $\begin{array}{l}-0.322 * \\
(0.351) \\
0.063\end{array}$ \\
\hline High-tech services & $\begin{array}{l}0.117 \\
(0.120) \\
0.289\end{array}$ & $\begin{array}{l}0.116 \\
(0.120) \\
0.293\end{array}$ & $\begin{array}{l}-0.061 \\
(0.102) \\
0.580\end{array}$ & $\begin{array}{l}0.181 \\
(0.116) \\
0.114\end{array}$ & $\begin{array}{l}-0.172 \\
(0.436) \\
0.249\end{array}$ \\
\hline $\mathrm{N}$ & 112 & 112 & 112 & 112 & 90 \\
\hline $\mathrm{R}$ square & 0.238 & 0.238 & 0.242 & 0.183 & 0.141 \\
\hline
\end{tabular}

Standard errors in parentheses; $\mathrm{p}$-values in italics $* * * \mathrm{p}<0.01, * * \mathrm{p}<0.05, * \mathrm{p}<0.10$ 


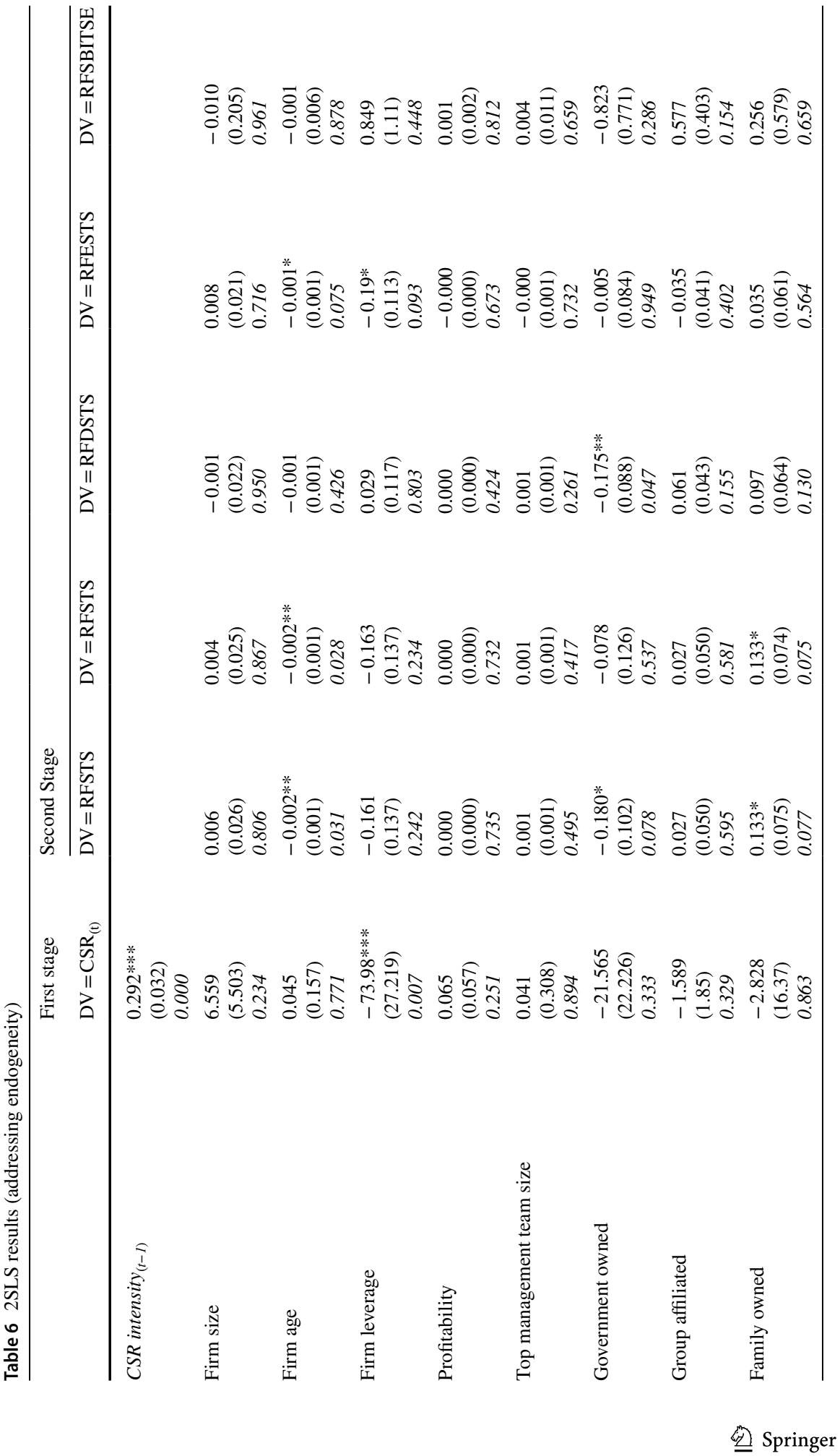




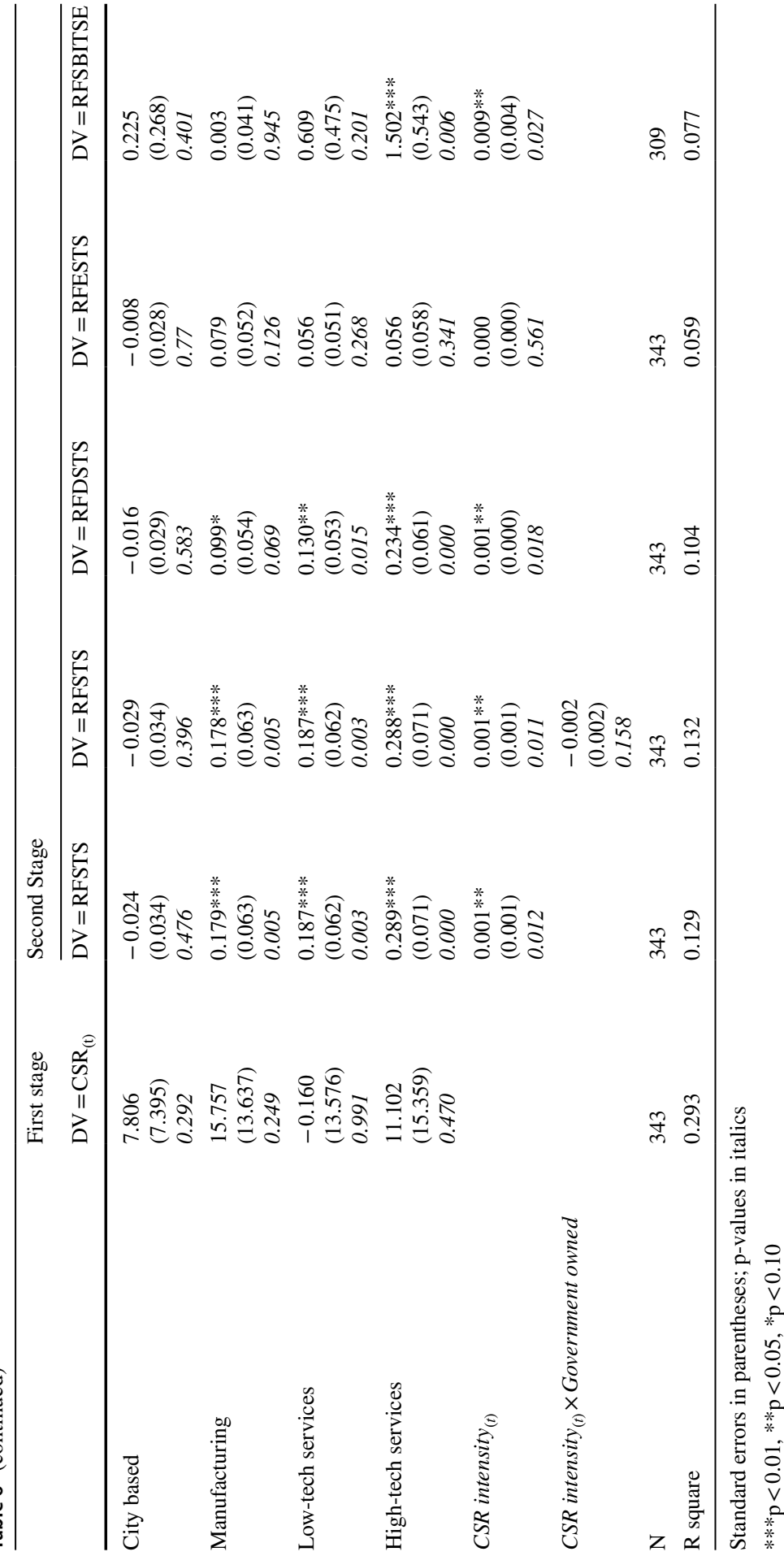


positive and significant effect on RFSTS and RFDSTS, thus reconfirming hypotheses 1 and 3a. In fact, Model 8 shows that hypothesis 3a is strongly supported (at the $1 \%$ significance level) in this test. However, we did not find support for our moderating effect of government ownership (hypothesis 2) using this variable.

Second, the effect of CSR on internationalisation can be endogenous. We addressed this endogeneity issue by using the instrumental variable approach and by using the two-stage least squares (2SLS) procedure. It is difficult to find good instrumental variables, as most of the factors that affect CSR are also likely to impact internationalisation. Therefore, as our instrumental variable, we used each firm's previous year's CSR intensity (i.e., for 2017 in our case), as indicated by the variable CSR intensity $_{(t-1)}$. Firms with greater levels of CSR intensity in the past would also be likely to spend proportionately more on CSR in the next year. By using this variable, however, our sample was reduced to half $(\mathrm{N}=343)$ due to missing values in the CSR reporting data for the previous year. The results from the 2SLS procedure are shown in Table 6. Our results remained largely consistent with the previous models, thereby suggesting that the positive association between domestic CSR and internationalisation is not driven by endogeneity issues. In fact, compared to the main analysis, hypotheses $3 \mathrm{a}$ and $3 \mathrm{~b}$ are better supported $(\mathrm{p}<0.05)$ in the $2 \mathrm{SLS}$ model.

\section{Discussion and Conclusions}

Our study was inspired by ongoing research on the relationship between CSR and internationalisation (Attig et al., 2016; Bondy \& Starkey, 2014; Cheung et al., 2015), and our aim was to examine the extent to which EMNEs' domestic CSR impacts their prospects of internationalisation. Engaging in CSR activities is widely known to improve organisational legitimacy (Zhao, 2012; Zheng et al., 2015), and this is even more important for EMNEs, as they face greater liabilities of origin during internationalisation (Marano et al., 2017; Stevens \& Shenkar, 2012; Tashman et al., 2019).

Our findings provide support for three out of four of our hypotheses. First and foremost, with regard to our first hypothesis, we had argued that domestic CSR intensity will improve the scope of internationalisation for EMNEs. This is because greater levels of domestic CSR improve EMNEs' nonmarket firm-specific advantages that can then be leveraged across borders. Domestic CSR also reduces EMNEs' liabilities of origin (Marano et al., 2017) and imparts EMNEs with greater legitimacy and reputation when they engage in internationalisation. Our results support this, and we find that for Indian MNEs, for every unit increase in CSR intensity, the scope of internationalisation (i.e., foreign investment) increases by $10.5 \%$ (Table 4, Model 1). The size of the effect is small in our case, but we suggest that this may depend on the size of the home country in which EMNEs are based. As India is a large emerging economy, there is a relatively greater scope of expansion within the home market than overseas. Our findings are in line with some past studies, which argued that greater spending on CSR is symbolic of the fact that the firm cares about the welfare of its domestic stakeholders and that this enhances 
organisational legitimacy and reputation among international stakeholders (GodosDíez et al., 2018).

Second, in hypothesis 2, we had argued that the positive effect of domestic CSR on internationalisation is reduced for government-owned EMNEs. This is because government-owned EMNEs have 'ascribed' nonmarket advantages (Deng et al., 2018) and play a distinct role in contributing to socioeconomic development in their home country (Cheung et al., 2015). Therefore, although government-owned EMNEs also have to report their CSR, they do not face the same stakeholder pressures as private firms and may have opportunity costs in investing in CSR to the same degree as private firms. Therefore, the utility of their domestic CSR in undertaking internationalisation would be reduced. This is also supported by our findings. Table 4 (Model 2) shows that while the effect of Indian MNEs' CSR on internationalisation is positive and significant, the effect of the interaction term (CSR intensity $\times$ Government owned) is negative and significant, although the significance is weak (at the 10\% level). Past research on the effect of EMNEs' state ownership on their internationalisation has emphasised upon the direct advantages of government ownership, such as easier access to funding and state support when investing in risky host environments (Cui \& Jiang, 2012; Duanmu, 2014; Ramasamy et al., 2012; Yin \& Zhang, 2012). There has also been an ongoing discussion in the literature about the value of CSR by SOEs in emerging economies (Khalid et al., 2021; Shahab et al., 2019; Wang et al., 2018; Zhu et al., 2016). Our finding implies that state ownership enables EMNEs to reduce their domestic CSR intensity insofar as the effect on internationalisation is concerned. Comparatively, privately owned EMNEs suffer from greater levels of liabilities of origin when investing overseas (Fiaschi et al., 2017; Marano et al., 2017) and benefit from domestic CSR to a greater extent when undertaking internationalisation.

Finally, in our third set of hypotheses, we had argued that the positive effect of domestic CSR on internationalisation is greater when EMNEs are internationalising into developed countries than in other emerging economies (hypothesis 3a). Regulations concerning firms' social and environmental impacts are more stringent in developed countries (Blowfield \& Frynas, 2005), and firms in such countries face greater pressure on mandatory CSR reporting (Gugler \& Shi, 2009). The amount of civil society pressure is also greater in developed countries (Fiaschi et al., 2017), where CSR is largely driven by the societal concerns of investors, NGOs, campaign groups and consumers (Gugler \& Shi, 2009). EMNEs that increase their domestic CSR are therefore able to match international expectations concerning CSR in developed countries (Gugler \& Shi, 2009). Our findings provide support for these arguments. As seen in our Table 4 (Models 3 and 4), the effect of domestic CSR intensity is positive and significant when Indian firms' internationalisation is directed to developed countries (i.e., RFDSTS), while the effect is not significant when the internationalisation is directed to other emerging economies (i.e., RFESTS). We had also expected that when EMNEs invest in other emerging economies, the effect of domestic CSR on their scope of internationalisation would be greater in emerging economies with relatively better (or stronger) institutions (hypothesis 3b). However, this was not fully supported by our data; specifically, it was supported using 2SLS but not in the OLS regression. An explanation of this outcome could be that 
a marginal increase in the strength of host institutions may not engender the same liabilities of origin as compared to when host institutions are much stronger and distant (as in developed countries). However, this suggestion warrants further research.

Overall, our paper makes several contributions to the literature. We mainly contribute to studies that focus on the domestic nonmarket capabilities of firms that are useful in their internationalisation (Cui \& Jiang, 2012; Fernández-Méndez et al., 2018; Frynas et al., 2006; Holburn \& Zelner, 2010). In emerging economies, especially China, it has been found that firms' domestic political connections enable them to directly gain preferential access to state-controlled resources, financial aid and special incentives that may facilitate their international expansion (Cui \& Jiang, 2012). We extend this by suggesting that domestic CSR is also an important nonmarket factor for EMNEs in expanding internationally, given the greater levels of institutional constraints faced by them during internationalisation. We thus also contribute to prior studies on the internationalisation of EMNEs by focusing on their CSR as an important firm-specific advantage (Buckley et al., 2014; Chittoor et al., 2015; Volchek et al., 2013; Zheng et al., 2015).

Past research on the relationship between CSR and internationalisation suggests that when firms internationalise, they are more likely to engage in CSR (Attig et al., 2016; Cheung et al., 2015). That is, the internationalisation of firms has been argued to normally occur first, followed by an interest in generating a 'social licence to operate' in specific host countries, which subsequently causes firms to initiate greater CSR development (Godos-Díez et al., 2018; Mithani, 2017; Pant \& Ramachandran, 2017). Highly internationalised firms may wish to perform more CSR activities not only because they attract more visibility and scrutiny from international media and other non-governmental organisations (NGOs) (Hah \& Freeman, 2014) but also due to the greater amount of slack resources that may be available to them (Dahan et al., 2006) and the larger amount of risk they face if industrial accidents were to occur (Laudal, 2011). Thus, while much of the prior research in this area has focused on how internationalisation impacts CSR (Attig et al., 2016; Bondy \& Starkey, 2014), ours is one of the few studies that have recently focused on the extent to which domestic CSR impacts internationalisation, especially for EMNEs (Agnihotri \& Bhattacharya, 2019a; Fiaschi et al., 2017). In this context, we theoretically contribute to the institutional and strategic perspectives on CSR by suggesting that the legitimisation benefits of CSR hold not only in their domestic environments but also in expanding to foreign markets.

Our study also provides some important practical implications for managers of EMNEs interested in internationalisation. As internationalisation is relatively riskier and costlier for EMNEs (compared to their developed country counterparts) due to EMNEs' relatively weaker technological advantages and greater liabilities of origin, we highlight that domestic CSR can reduce these disadvantages and liabilities via the development of trust and legitimacy among global stakeholders. Such advantages of domestic CSR are even greater when EMNEs intend to create foreign subsidiaries in developed countries and when they do not have other nonmarket advantages. Marano et al. (2017) suggest that EMNEs must move beyond 'ceremonial' CSR reporting (or making ambiguous CSR claims), as this approach is being increasingly scrutinised by global stakeholders and may cause further damage to 
trust when EMNEs' CSR reports contradict their actual CSR activities. Our study reinforces this by examining the extent of EMNEs' CSR expenditures, which provide a better indication of their realistic commitment to CSR, to positively impact their internationalisation prospects.

Like most academic studies, however, our study also has a number of limitations that provide worthwhile avenues for future research. First, our data are limited to the internationalisation of firms from a single emerging market (i.e., India) and for a single year (i.e., 2018). Although our sample includes a good number of firms (i.e., 686), including more years (i.e., using a panel dataset) would have added more robustness to our research; however Orbis reports the internationalisation information (i.e., subsidiary formation) for the most recent year only. On that note, we also include only one measure (i.e., scope) of internationalisation based on the ratio of foreign subsidiaries to total subsidiaries, whereas several other measures exist, such as export intensity and the ratio of foreign sales to total sales. Thus, future research could benefit from a greater number of home countries, years and internationalisation measures. Second, we also include only CSR expenditures as reported by firms as a measure of CSR. Again, CSR is a broad concept; firms may engage in socially responsible activities in a variety of ways that we are unable to capture herein. Thus, future research could take this into account and capture the breadth of different CSR activities. It is also important to consider that while domestic CSR is important in gaining legitimacy and reputation for firm internationalisation, corporate-level CSR policies that stretch beyond borders and across countries could become more important for MNEs with time. Unfortunately, at this point, we do not have these data about corporate-level or international CSR, and future research can account for this. Finally, although we examine the moderating effect of government ownership (as an ascribed nonmarket advantage) on the relationship between the domestic CSR of EMNEs and their internationalisation, there could be other ways through which firms acquire nonmarket advantages (such as via political connections and other political activities). Future research could examine the complementarity of CSR with other nonmarket strategies.

In conclusion, our study addresses the growing contemporary issue of whether domestic nonmarket capabilities impact the internationalisation of EMNEs. It emphasises the importance of the ways through which domestic CSR can reduce the liabilities of origin faced by EMNEs in internationalisation through improved legitimacy and reputation among international stakeholders.

Open Access This article is licensed under a Creative Commons Attribution 4.0 International License, which permits use, sharing, adaptation, distribution and reproduction in any medium or format, as long as you give appropriate credit to the original author(s) and the source, provide a link to the Creative Commons licence, and indicate if changes were made. The images or other third party material in this article are included in the article's Creative Commons licence, unless indicated otherwise in a credit line to the material. If material is not included in the article's Creative Commons licence and your intended use is not permitted by statutory regulation or exceeds the permitted use, you will need to obtain permission directly from the copyright holder. To view a copy of this licence, visit http://creativecommons.org/licen ses/by/4.0/. 


\section{References}

Agnihotri, A., \& Bhattacharya, S. (2019a). Communicating CSR practices-Role of internationalization of emerging market firms. Journal of Marketing Communications, 25(4), 365-384.

Agnihotri, A., \& Bhattacharya, S. (2019b). Unethical consumer behavior: The role of institutional and socio-cultural factors. Journal of Consumer Marketing, 36(1), 124-135.

Aswani, J., Chidambaran, N., \& Hasan, I. (2020). Who benefits from mandatory CSR? Evidence from the Indian Companies Act 2013. Emerging Markets Review, 46, 100753.

Attig, N., Boubakri, N., El Ghoul, S., \& Guedhami, O. (2016). Firm internationalization and corporate social responsibility. Journal of Business Ethics, 134(2), 171-197.

Awate, S., Larsen, M. M., \& Mudambi, R. (2012). EMNE catch-up strategies in the wind turbine industry: Is there a trade-off between output and innovation capabilities? Global Strategy Journal, 2(3), 205-223.

Banerjee, S. (2020). Institutionalization of corporate social responsibility (CSR) in India and its effects on CSR reporting: A case study of the petroleum and gas industry. In N. Mitra \& R. Schmidpeter (Eds.), Mandated Corporate Social Responsibility (pp. 141-157). Springer.

Bangara, A., Freeman, S., \& Schroder, W. (2012). Legitimacy and accelerated internationalisation: An Indian perspective. Journal of World Business, 47(4), 623-634. https://doi.org/10.1016/j.jwb.2011. 09.002 .

Bhanji, Z., \& Oxley, J. E. (2013). Overcoming the dual liability of foreignness and privateness in international corporate citizenship partnerships. Journal of International Business Studies, 44(4), 290311. https://doi.org/10.1057/jibs.2013.8.

Bhaumik, S. K., Driffield, N., \& Zhou, Y. (2016). Country specific advantage, firm specific advantage and multinationality-Sources of competitive advantage in emerging markets: Evidence from the electronics industry in China. International Business Review, 25(1), 165-176.

Blowfield, M., \& Frynas, J. G. (2005). Editorial Setting new agendas: Critical perspectives on Corporate Social Responsibility in the developing world. International Affairs, 81(3), 499-513.

Bondy, K., \& Starkey, K. (2014). The dilemmas of internationalization: Corporate social responsibility in the multinational corporation. British Journal of Management, 25(1), 4-22.

Buckley, P. J. (2018). Internalisation theory and outward direct investment by emerging market multinationals. Management International Review, 58(2), 195-224.

Buckley, P. J., \& Casson, M. C. (1998). Analyzing foreign market entry strategies: Extending the internalization approach. Journal of International Business Studies, 29(3), 539-561.

Buckley, P. J., Clegg, L. J., Cross, A. R., Liu, X., Voss, H. \& Zheng, P. (2015). The determinants of Chinese outward foreign direct investment. In P. J. Buckley (Ed.), International Business Strategy (pp. 588-614). Routledge.

Buckley, P. J., Elia, S., \& Kafouros, M. (2014). Acquisitions by emerging market multinationals: Implications for firm performance. Journal of World Business, 49(4), 611-632.

Caligiuri, P., Lazarova, M., \& Zehetbauer, S. (2004). Top managers' national diversity and boundary spanning. Journal of Management Development, 23(9), 848-859.

Caussat, P., Prime, N., \& Wilken, R. (2019). How multinational banks in india gain legitimacy: Organisational practices and resources required for implementation. Management International Review, 59(4), 561-591. https://doi.org/10.1007/s11575-019-00387-6.

Chan, R. Y., \& Ma, K. H. (2016). Environmental orientation of exporting SMEs from an emerging economy: Its antecedents and consequences. Management International Review, 56(5), 597-632.

Chao, M.C.-H., \& Kumar, V. (2010). The impact of institutional distance on the international diversityperformance relationship. Journal of World Business, 45(1), 93-103.

Chaudhry, D., Tomar, P., \& Joshi, P. (2018). Deconstructing Indian overseas foreign direct investments: Historical and contemporary trends. Indian Council for Research on International Economic Relations.

Cheung, Y.-L., Kong, D., Tan, W., \& Wang, W. (2015). Being good when being international in an emerging economy: The case of China. Journal of Business Ethics, 130(4), 805-817.

Child, J., \& Tsai, T. (2005). The dynamic between firms' environmental strategies and institutional constraints in emerging economies: Evidence from China and Taiwan. Journal of Management Studies, 42(1), 95-125. 
Chittoor, R., Aulakh, P. S., \& Ray, S. (2015). What drives overseas acquisitions by Indian firms? A behavioral risk-taking perspective. Management International Review, 55(2), 255-275. https://doi. org/10.1007/s11575-015-0238-7

Cuervo-Cazurra, A. (2008). The multinationalization of developing country MNEs: The case of multilatinas. Journal of International Management, 14(2), 138-154.

Cui, L., \& Jiang, F. (2012). State ownership effect on firms' FDI ownership decisions under institutional pressure: A study of Chinese outward-investing firms. Journal of International Business Studies, 43(3), 264-284.

Dahan, N., Doh, J., \& Guay, T. (2006). The role of multinational corporations in transnational institution building: A policy network perspective. Human Relations, 59(11), 1571-1600.

Deng, Z., Yan, J., \& van Essen, M. (2018). Heterogeneity of political connections and outward foreign direct investment. International Business Review, 27(4), 893-903.

Detomasi, D. (2007). The multinational corporation and global governance: Modelling global public policy networks. Journal of Business Ethics, 71(3), 321-334. https://doi.org/10.1007/ s10551-006-9141-2

Drahos, P., \& Braithwaite, J. (2001). The globalisation of regulation. Journal of Political Philosophy, 9(1), 103-128.

Du, X., \& Luo, J.-H. (2016). Political connections, home formal institutions, and internationalization: Evidence from China. Management and Organization Review, 12(1), 103-133. https://doi.org/10. $1017 /$ mor.2015.40

Duanmu, J.-L. (2014). State-owned MNCs and host country expropriation risk: The role of home state soft power and economic gunboat diplomacy. Journal of International Business Studies, 45(8), 1044-1060.

Dunning, J. H. (2000). The eclectic paradigm as an envelope for economic and business theories of MNE activity. International Business Review, 9(2), 163-190.

Dutta, D. K., Malhotra, S., \& Zhu, P. (2016). Internationalization process, impact of slack resources, and role of the CEO: The duality of structure and agency in evolution of cross-border acquisition decisions. Journal of World Business, 51(2), 212-225.

Economic-Times. (2020). India moves up a rank to become second-largest source of FDI for UK. Retrieved January 1, 2021, from https://economictimes.indiatimes.com/news/international/busin ess/india-moves-up-a-rank-to-become-second-largest-source-of-fdi-for-uk/articleshow/76897637. cms?utm_source=contentofinterest\&utm_medium $=$ text\&utm_campaign $=$ cppst

Eden, L., \& Miller, S. R. (2004). Distance matters: Liability of foreignness, institutional distance and ownership strategy. Advances in International Management, 16, 187-221.

Erramilli, M. K., Agarwal, S., \& Kim, S.-S. (1997). Are firm-specific advantages location-specific too? Journal of International Business Studies, 28(4), 735-757.

Fernández-Méndez, L., García-Canal, E., \& Guillén, M. F. (2018). Domestic political connections and international expansion: It's not only 'who you know' that matters. Journal of World Business, 53(5), 695-711. https://doi.org/10.1016/j.jwb.2018.03.006

Fiaschi, D., Giuliani, E., \& Nieri, F. (2017). Overcoming the liability of origin by doing no-harm: Emerging country firms' social irresponsibility as they go global. Journal of World Business, 52(4), $546-563$.

Fombrun, C., \& Shanley, M. (1990). What's in a name? Reputation building and corporate strategy. Academy of Management Journal, 33(2), 233-258.

Friel, D. (2021). Breaking the looking glass: Understanding how emerging market multinationals develop unique firm-specific advantages. Journal of International Management, 27(3), 100831.

Frynas, J., Mellahi, K., \& Pigman, G. A. (2006). First mover advantages in international business and firm-specific political resources. Strategic Management Journal, 27(4), 321-345.

Gaur, A. S., \& Lu, J. W. (2007). Ownership strategies and survival of foreign subsidiaries: Impacts of institutional distance and experience. Journal of Management, 33(1), 84-110.

Godos-Díez, J.-L., Cabeza-García, L., \& Fernández-González, C. (2018). Relationship between corporate social responsibility (CSR) and internationalisation strategies: A descriptive study in the Spanish context. Administrative Sciences, 8(4), 57.

Gugler, P., \& Shi, J. Y. (2009). Corporate social responsibility for developing country multinational corporations: Lost war in pertaining global competitiveness? Journal of Business Ethics, 87(1), 3-24.

Hadjikhani, A., Leite, E., \& Pahlberg, C. (2019). Business and socio-political interaction in international service projects: The case of Brazil. Management International Review, 59(1), 171-200. https:// doi.org/10.1007/s11575-018-0368-9 
Hah, K., \& Freeman, S. (2014). Multinational enterprise subsidiaries and their CSR: A conceptual framework of the management of CSR in smaller emerging economies. Journal of Business Ethics, 122(1), 125-136.

Hernandez, E., \& Guillén, M. F. (2018). What's theoretically novel about emerging-market multinationals? Journal of International Business Studies, 49(1), 24-33.

Hernández, V., \& Nieto, M. J. (2015). The effect of the magnitude and direction of institutional distance on the choice of international entry modes. Journal of World Business, 50(1), 122-132.

Hernández, V., Nieto, M. J., \& Boellis, A. (2018). The asymmetric effect of institutional distance on international location: Family versus nonfamily firms. Global Strategy Journal, 8(1), 22-45.

Holburn, G. L., \& Zelner, B. A. (2010). Political capabilities, policy risk, and international investment strategy: Evidence from the global electric power generation industry. Strategic Management Journal, 31(12), 1290-1315.

Hong, G., \& Kim, E. (2017). Overcoming country-of-origin image constraints on hiring: The moderating role of CSR. Asian Business and Management, 16(4-5), 253-271.

Husted, B. W., \& Allen, D. B. (2007). Strategic corporate social responsibility and value creation among large firms: Lessons from the Spanish experience. Long Range Planning, 40(6), 594-610.

Kalasin, K., Cuervo-Cazurra, A., \& Ramamurti, R. (2020). State ownership and international expansion: The S-curve relationship. Global Strategy Journal, 10(2), 386-418.

Kaufmann, D., Kraay, A., \& Mastruzzi, M. (2010). The worldwide governance indicators: Methodology and analytical issues. World Bank policy research working paper (5430).

Kedia, S., \& Mozumdar, A. (2003). Foreign currency-denominated debt: An empirical examination. The Journal of Business, 76(4), 521-546.

Khalid, F., Sun, J., Huang, G., \& Su, C.-Y. (2021). Environmental, social and governance performance of Chinese multinationals: A comparison of state- and non-state-owned enterprises. Sustainability, 13(7), 4020. https://www.mdpi.com/2071-1050/13/7/4020

Khanna, T., \& Palepu, K. (2000). The future of business groups in emerging markets: Long-run evidence from Chile. Academy of Management Journal, 43(3), 268-285.

Konara, P., \& Shirodkar, V. (2018). Regulatory institutional distance and MNCs' subsidiary performance: Climbing up vs. climbing down the institutional ladder. Journal of International Management, 24(4), 333-347.

Kotha, S., Rindova, V. P., \& Rothaermel, F. T. (2001). Assets and actions: Firm-specific factors in the internationalization of US Internet firms. Journal of International Business Studies, 32(4), 769-791.

Krichewsky, D. (2017). CSR public policies in India's democracy. FIW Working Paper, 06.

Krichewsky, D. (2019). Corporate Social Responsibility and Economic Responsiveness in India. Cambridge University Press.

Kumar, V., Gaur, A. S., \& Pattnaik, C. (2012). Product diversification and international expansion of business groups. Management International Review, 52(2), 175-192. https://doi.org/10.1007/ s11575-012-0133-4

Lattemann, C., Fetscherin, M., Alon, I., Li, S., \& Schneider, A. M. (2009). CSR communication intensity in Chinese and Indian multinational companies. Corporate Governance: An International Review, 17(4), 426-442.

Laudal, T. (2011). Drivers and barriers of CSR and the size and internationalization of firms. Social Responsibility Journal, 7(2), 234-256.

Lee, I. H., \& Rugman, A. M. (2012). Firm-specific advantages, inward FDI origins, and performance of multinational enterprises. Journal of International Management, 18(2), 132-146.

Leonidou, L. C., Fotiadis, T. A., Christodoulides, P., Spyropoulou, S., \& Katsikeas, C. S. (2015). Environmentally friendly export business strategy: Its determinants and effects on competitive advantage and performance. International Business Review, 24(5), 798-811.

Li, S., Fetscherin, M., Alon, I., Lattemann, C., \& Yeh, K. (2010). Corporate social responsibility in emerging markets. Management International Review, 50(5), 635-654.

Li, T., \& Belal, A. (2018). Authoritarian state, global expansion and corporate social responsibility reporting: The narrative of a Chinese state-owned enterprise. Accounting forum, 42(2), 199-217.

Marano, V., \& Kostova, T. (2016). Unpacking the institutional complexity in adoption of CSR practices in multinational enterprises. Journal of Management Studies, 53(1), 28-54.

Marano, V., \& Tashman, P. (2012). MNE/NGO partnerships and the legitimacy of the firm. International Business Review, 21(6), 1122-1130. 
Marano, V., Tashman, P., \& Kostova, T. (2017). Escaping the iron cage: Liabilities of origin and CSR reporting of emerging market multinational enterprises. Journal of International Business Studies, 48(3), 386-408. https://doi.org/10.1057/jibs.2016.17

Marques, A. C., \& Srinivasan, P. (2018). When corporate social responsibility is an obligation: The unique case of India. IIM Bangalore Research Paper (565).

Matten, D., Crane, A., \& Chapple, W. (2003). Behind the mask: Revealing the true face of corporate citizenship. Journal of Business Ethics, 45(1-2), 109-120.

Matten, D., \& Moon, J. (2008). "Implicit" and "explicit" CSR: A conceptual framework for a comparative understanding of corporate social responsibility. Academy of Management Review, 33(2), 404-424.

Mezias, J. M. (2002). How to identify liabilities of foreignness and assess their effects on multinational corporations. Journal of International Management, 8(3), 265-282.

Mithani, M. A. (2017). Innovation and CSR-Do they go well together? Long Range Planning, 50(6), 699-711.

Mohr, A., \& Batsakis, G. (2019). The contingent effect of TMT international experience on firms' internationalization speed. British Journal of Management, 30(4), 869-887.

Mukherjee, A., \& Bird, R. (2016). Analysis of mandatory CSR expenditure in India: A survey. International Journal of Corporate Governance, 7(1), 32-59.

National-CSR-Portal. (2020). Ministry of Corporate Affairs: Government of India. Retrieved May 19, 2020, from https://www.csr.gov.in/

Newenham-Kahindi, A., \& Stevens, C. E. (2018). An institutional logics approach to liability of foreignness: The case of mining MNEs in Sub-Saharan Africa. Journal of International Business Studies, 49(7), 881-901.

North, D. (1996). Privatization, incentives and economic performance. In T. Anderson \& P. Hill (Eds.), The Privatization Process: A Worldwide Perspective. Rowman and Littlefield Publishers, Inc.

Nuruzzaman, N., Singh, D., \& Gaur, A. S. (2020). Institutional support, hazards, and internationalization of emerging market firms. Global Strategy Journal, 10(2), 361-385.

Pant, A., \& Ramachandran, J. (2017). Navigating identity duality in multinational subsidiaries: A paradox lens on identity claims at Hindustan Unilever 1959-2015. Journal of International Business Studies, 48(6), 664-692.

Pattnaik, C., Singh, D., \& Gaur, A. S. (2021). Home country learning and international expansion of emerging market multinationals. Journal of International Management, 27(3),

Perea, J. R., \& Stephenson, M. (2018). Outward FDI from developing countries. In World Bank, Global Investment Competitiveness Report 2017/2018 (pp. 101-134). World Bank Group.

Rajak, D. (2011). In good company: An anatomy of corporate social responsibility. Stanford University Press.

Ramamurti, R. (2012). What is really different about emerging market multinationals? Global Strategy Journal, 2(1), 41-47.

Ramasamy, B., Yeung, M., \& Laforet, S. (2012). China's outward foreign direct investment: Location choice and firm ownership. Journal of World Business, 47(1), 17-25.

Roper, J., \& Schoenberger-Orgad, M. (2011). State-owned enterprises: Issues of accountability and legitimacy. Management Communication Quarterly, 25(4), 693-709.

Rugman, A. M., \& Oh, C. H. (2011). Methodological issues in the measurement of multinationality of US firms. Multinational Business Review, 19(3), 202-212.

Rugman, A. M., \& Verbeke, A. (1992). A note on the transnational solution and the transaction cost theory of multinational strategic management. Journal of International Business Studies, 23, $761-771$.

Saikia, M., Das, K. C., \& Borbora, S. (2020). What drives the boom in outward FDI from India? International Journal of Emerging Markets, 15(5), 899-922.

Salomon, R., \& Wu, Z. (2012). Institutional distance and local isomorphism strategy. Journal of International Business Studies, 43(4), 343-367.

Schroeder, M. A., Lander, J., \& Levine-Silverman, S. (1990). Diagnosing and dealing with multicollinearity. Western Journal of Nursing Research, 12(2), 175-187.

Scott-Kennel, J., \& Giroud, A. (2015). MNEs and FSAs: Network knowledge, strategic orientation and performance. Journal of World Business, 50(1), 94-107.

Shahab, Y., Ntim, C. G., \& Ullah, F. (2019). The brighter side of being socially responsible: CSR ratings and financial distress among Chinese state and non-state owned firms. Applied Economics Letters, 26(3), 180-186. 
Shirodkar, V., Beddewela, E., \& Richter, U. H. (2018). Firm-level determinants of political CSR in emerging economies: Evidence from India. Journal of Business Ethics, 148(3), 673-688.

Shirodkar, V., \& Konara, P. (2017). Institutional distance and foreign subsidiary performance in emerging markets: Moderating effects of ownership strategy and host-country experience. Management International Review, 57(2), 179-207.

Stevens, C. E., \& Shenkar, O. (2012). The liability of home: Institutional friction and firm disadvantage abroad. Advances in International Management, 25, 127-148.

Stevens, C. E., Xie, E., \& Peng, M. W. (2016). Toward a legitimacy-based view of political risk: The case of Google and Yahoo in China. Strategic Management Journal, 37(5), 945-963.

Subramaniam, N., Kansal, M., \& Babu, S. (2017). Governance of mandated corporate social responsibility: Evidence from Indian government-owned firms. Journal of Business Ethics, 143(3), 543-563.

Tashman, P., Marano, V., \& Kostova, T. (2019). Walking the walk or talking the talk? Corporate social responsibility decoupling in emerging market multinationals. Journal of International Business Studies, 50(2), 153-171. https://doi.org/10.1057/s41267-018-0171-7.

Tendolkar, A. (2019). More companies spending on CSR but aren't being generous enough. Bloomberg Quint. Retrieved January 15, 2021, from https://www.bloombergquint.com/business/morec ompanies-spending-on-csr-but-arent-being-generous-enoug

Volchek, D., Jantunen, A., \& Saarenketo, S. (2013). The institutional environment for international entrepreneurship in Russia: Reflections on growth decisions and performance in SMEs. Journal of International Entrepreneurship, 11(4), 320-350.

Wang, Z., Reimsbach, D., \& Braam, G. (2018). Political embeddedness and the diffusion of corporate social responsibility practices in China: A trade-off between financial and CSR performance? Journal of Cleaner Production, 198, 1185-1197.

Wei, Z., \& Nguyen, Q. T. (2017). Subsidiary strategy of emerging market multinationals: A home country institutional perspective. International Business Review, 26(5), 1009-1021.

Witt, M. A., \& Lewin, A. Y. (2007). Outward foreign direct investment as escape response to home country institutional constraints. Journal of International Business Studies, 38(4), 579-594.

Wright, M., Filatotchev, I., Hoskisson, R. E., \& Peng, M. W. (2005). Strategy research in emerging economies: Challenging the conventional wisdom. Journal of Management Studies, 42(1), 1-33.

Wu, J., Wang, C., Hong, J., Piperopoulos, P., \& Zhuo, S. (2016). Internationalization and innovation performance of emerging market enterprises: The role of host-country institutional development. Journal of World Business, 51(2), 251-263.

Xia, J., Ma, X., Lu, J. W., \& Yiu, D. W. (2014). Outward foreign direct investment by emerging market firms: A resource dependence logic. Strategic Management Journal, 35(9), 1343-1363.

Yan, Z. J., Zhu, J. C., Fan, D., \& Kalfadellis, P. (2018). An institutional work view toward the internationalization of emerging market firms. Journal of World Business, 53(5), 682-694. https://doi.org/10. 1016/j.jwb.2018.03.008

Yin, J., \& Zhang, Y. (2012). Institutional dynamics and corporate social responsibility (CSR) in an emerging country context: Evidence from China. Journal of Business Ethics, 111(2), 301-316.

Zaheer, S. (1995). Overcoming the liability of foreignness. Academy of Management Journal, 38(2), $341-363$.

Zhao, M. (2012). CSR-based political legitimacy strategy: Managing the state by doing good in China and Russia. Journal of Business Ethics, 111(4), 439-460.

Zheng, Q., Luo, Y., \& Maksimov, V. (2015). Achieving legitimacy through corporate social responsibility: The case of emerging economy firms. Journal of World Business, 50(3), 389-403.

Zhou, N. (2018). Hybrid state-owned enterprises and internationalization: Evidence from emerging market multinationals. Management International Review, 58(4), 605-631.

Zhu, Q., Liu, J., \& Lai, K.-H. (2016). Corporate social responsibility practices and performance improvement among Chinese national state-owned enterprises. International Journal of Production Economics, $171,417-426$.

Publisher's Note Springer Nature remains neutral with regard to jurisdictional claims in published maps and institutional affiliations. 